\title{
Subseasonal Variability Associated with Asian Summer Monsoon Simulated by 14 IPCC AR4 Coupled GCMs
}

\author{
JIA-LIN LIN \\ NOAA/ESRL, CIRES Climate Diagnostics Center, Boulder, Colorado, and Department of Geography, The Ohio State University, \\ Columbus, Ohio
}

Klaus M. Weickman and George N. Kiladis

Department of Geography, The Ohio State University, Columbus, Ohio

BRIAN E. MAPES

RSMAS, University of Miami, Miami, Florida

Siegfried D. Schubert And Max J. Suarez

NASA GSFC Global Modeling and Assimilation Office, Greenbelt, Maryland

Julio T. BACMEISTER AND Myong-In LeE

NASA GSFC Global Modeling and Assimilation Office, Greenbelt, and Goddard Earth Sciences and Technology Center, University of Maryland, Baltimore County, Baltimore, Maryland

(Manuscript received 14 December 2006, in final form 12 November 2008)

\begin{abstract}
This study evaluates the subseasonal variability associated with the Asian summer monsoon in 14 coupled general circulation models (GCMs) participating in the Intergovernmental Panel on Climate Change (IPCC) Fourth Assessment Report (AR4). Eight years of each model's twentieth-century climate simulation are analyzed. The authors focus on the three major components of Asian summer monsoon: the Indian summer monsoon (ISM), the western North Pacific summer monsoon (WNPSM), and the East Asian summer monsoon (EASM), together with the two dominant subseasonal modes: the eastward- and northwardpropagating boreal summer intraseasonal oscillation (BSIO) and the westward-propagating 12-24-day mode.

The results show that current state-of-the-art GCMs still have difficulties and display a wide range of skill in simulating the subseasonal variability associated with Asian summer monsoon. During boreal summer (May-October), most of the models produce reasonable seasonal-mean precipitation over the ISM region, but excessive precipitation over the WNPSM region and insufficient precipitation over the EASM region. In other words, models concentrate their rain too close to the equator in the western Pacific. Most of the models simulate overly weak total subseasonal (2-128 day) variance, as well as too little variance for BSIO and the 12-24-day mode. Only 4-5 models produce spectral peaks in the BSIO and 12-24-day frequency bands; instead, most of the models display too red a spectrum, that is, an overly strong persistence of precipitation. For the seven models with three-dimensional data available, five reproduce the preconditioning of moisture in BSIO but often with a too late starting time, and only three simulate the phase lead of low-level convergence. Interestingly, although models often have difficulty in simulating the eastward propagation of BSIO, they tend to simulate well the northward propagation of BSIO, together with the westward propagation of the 12-24-day mode. The northward propagation in these models is thus not simply a NW-SE-tilted tail protruding off of an eastward-moving deep-tropical intraseasonal oscillation.
\end{abstract}

Corresponding author address: Dr. Jia-Lin Lin, Department of Geography, The Ohio State University, 1105 Derby Hall, 154 North Oval Mall, Columbus, OH 43210.

E-mail: lin.789@osu.edu 


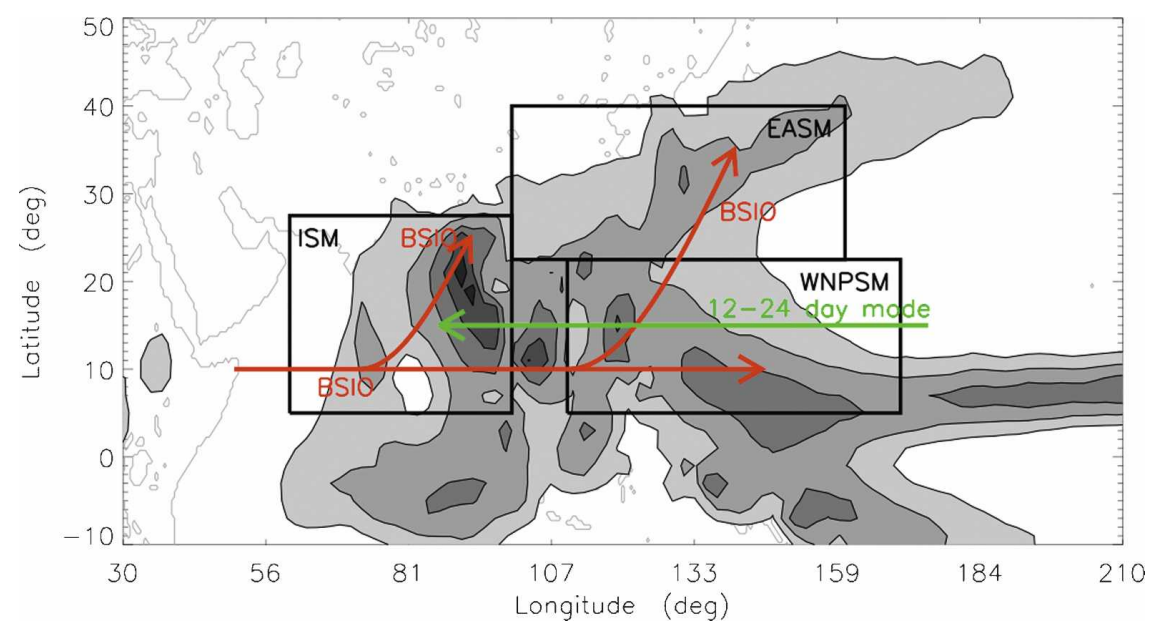

FIG. 1. Schematic depiction of the three major components of Asian summer monsoon and its two dominant subseasonal modes. Contours are the northern summer (May-October) seasonal-mean GPCP precipitation. The first contour is $4 \mathrm{~mm} \mathrm{day}^{-1}$ and contour interval is 2 $\mathrm{mm}$ day $^{-1}$.

\section{Introduction}

The Asian summer monsoon significantly affects the lives of more than $60 \%$ of the world's population. It has three major components (Fig. 1): the Indian summer monsoon (ISM), the East Asian summer monsoon (EASM), and the western north Pacific summer monsoon (WNPSM; see review by Wang and Linho 2002). It also has strong subseasonal variability with two dominant modes: an eastward- and northward-propagating boreal summer intraseasonal oscillation (BSIO) with a period of about 24-70 days (e.g., Yasunari 1979; Murakami and Nakazawa 1985; Lau and Chan 1986; Knutson et al. 1986; Wang and Rui 1990; Kemball-Cook and Wang 2001; Hsu and Weng 2001; Lawrence and Webster 2002; Straub and Kiladis 2003; Jiang et al. 2004; among many others), and a westward-propagating mode with a period of about 12-24 days (hereafter referred to as the 12-24-day mode; e.g., Krishnamurti and Ardanuy 1980; Murakami 1980; Lau et al. 1988; Lau and Lau 1990; Hartmann et al. 1992; Chen and Chen 1993, 1995; Kiladis and Weickmann 1997; Vincent et al. 1998; Fukutomi and Yasunari 1999, 2002; Chen et al. 2000). These subseasonal modes significantly affect the onset and breaks of all three monsoon regions, and the formation, intensity, and track of the tropical cyclones (e.g., Liebmann et al. 1994). Therefore, they are important for both weather prediction and climate prediction.

Unfortunately, the subseasonal variability of Asian summer monsoon has not been well simulated in general circulation models (GCMs) used for weather predictions, climate predictions, and climate projections (e.g., Sperber et al. 2000; Wu et al. 2002; Waliser et al.
$2003 a, b, c)$. For example, in an evaluation of the simulations of 10 atmospheric GCMs, Waliser et al. (2003c) found that the model BSIO patterns are typically less coherent, lack sufficient eastward propagation, and have smaller zonal and meridional spatial scales than the observed patterns, and are often limited to one side or the other of the Maritime Continent. The most pervasive and problematic feature of the models' depiction of intraseasonal variability and/or their BSIO patterns is the overall lack of variability in the equatorial Indian Ocean. These biases are detrimental to both weather prediction and climate prediction.

Factors that are possibly important for BSIO simulations include model physics, model resolution, and air-sea coupling. Most of the previous GCM sensitivity studies of BSIO simulation focused on the role of airsea coupling, and found that air-sea coupling significantly improves the BSIO signals (e.g., Kemball-Cook et al. 2002; Fu et al. 2003; Fu and Wang 2004a,b). However, changes in a model's mean state need to be taken into account (e.g., Kemball-Cook et al. 2002), which strongly affects wave-heating feedback in BSIO, for example, by providing the mean surface wind that determines the sign of wind-induced surface heat exchange (WISHE) feedback (Emanuel 1987; Neelin et al. 1987), or by providing strong equivalent linear mechanical damping making the BSIO a highly viscous oscillation (Lin et al. 2005).

Recently, in preparation for the Intergovernmental Panel on Climate Change (IPCC) Fourth Assessment Report (AR4), more than a dozen international climate modeling centers conducted a comprehensive set of long-term simulations for both the twentieth century's 
TABLE 1. List of models that participate in this study.

\begin{tabular}{|c|c|c|c|c|c|}
\hline Modeling groups & $\begin{array}{c}\text { IPCC ID } \\
\text { (label in figures) }\end{array}$ & $\begin{array}{l}\text { Grid type/ } \\
\text { resolution/ } \\
\text { model top }\end{array}$ & $\begin{array}{c}\text { Deep convection } \\
\text { scheme/modification }\end{array}$ & $\begin{array}{l}\text { Downdrafts* } \\
\text { SC/UC/ } \\
\text { meso }\end{array}$ & Closure/trigger \\
\hline $\begin{array}{c}\text { NOAA/Geophysical Fluid } \\
\text { Dynamics Laboratory }\end{array}$ & $\begin{array}{l}\text { GFDL CM2.0 } \\
\text { (GFDL2.0) }\end{array}$ & $\begin{array}{l}\text { Gridpoint } / 144 \times 90 \\
\text { L24/3 mb }\end{array}$ & $\begin{array}{l}\text { Moorthi and Suarez (1992)/ } \\
\text { Tokioka et al. (1988) }\end{array}$ & $\mathrm{N} / \mathrm{N} / \mathrm{N}$ & CAPE/threshold \\
\hline $\begin{array}{l}\text { NOAA/Geophysical Fluid } \\
\text { Dynamics Laboratory }\end{array}$ & $\begin{array}{l}\text { GFDL CM2.1 } \\
\text { (GFDL2.1) }\end{array}$ & $\begin{array}{l}\text { Gridpoint } / 144 \times 90 \\
\text { L24/3 mb }\end{array}$ & $\begin{array}{l}\text { Moorthi and Suarez (1992)/ } \\
\text { Tokioka et al. (1988) }\end{array}$ & $\mathrm{N} / \mathrm{N} / \mathrm{N}$ & CAPE/threshold \\
\hline $\begin{array}{l}\text { National Center for } \\
\text { Atmospheric Research }\end{array}$ & $\begin{array}{l}\text { CCSM3 } \\
\quad(\mathrm{CCSM} 3)\end{array}$ & $\begin{array}{l}\text { Spectral/T85-L26/ } \\
2.2 \mathrm{mb}\end{array}$ & $\begin{array}{l}\text { Zhang and McFarlane } \\
\text { (1995) }\end{array}$ & $\mathrm{Y} / \mathrm{N} / \mathrm{N}$ & CAPE \\
\hline $\begin{array}{l}\text { National Center for } \\
\text { Atmospheric Research }\end{array}$ & $\begin{array}{l}\text { PCM } \\
\quad(\mathrm{PCM})\end{array}$ & $\begin{array}{l}\text { Spectral/T42-L26/ } \\
2.2 \mathrm{mb}\end{array}$ & $\begin{array}{l}\text { Zhang and McFarlane } \\
\text { (1995) }\end{array}$ & $\mathrm{Y} / \mathrm{N} / \mathrm{N}$ & CAPE \\
\hline $\begin{array}{l}\text { NASA Goddard Institute } \\
\text { for Space Studies }\end{array}$ & $\begin{array}{l}\text { GISS-AOM } \\
\quad(\text { GISS-AOM) }\end{array}$ & $\begin{array}{l}\text { Gridpoint/90 } \times 60 \\
\quad \text { L12 }\end{array}$ & Russell et al. (1995) & $\mathrm{N} / \mathrm{N} / \mathrm{N}$ & CAPE \\
\hline $\begin{array}{l}\text { NASA Goddard Institute } \\
\text { for Space Studies }\end{array}$ & $\begin{array}{l}\text { GISS-ER } \\
\text { (GISS-ER) }\end{array}$ & $\begin{array}{l}\text { Gridpoint } / 72 \times 46 \\
\text { L20/0.1 mb }\end{array}$ & $\begin{array}{l}\text { Del Genio and Yao } \\
\text { (1993) }\end{array}$ & $\mathrm{Y} / \mathrm{N} / \mathrm{N}$ & $\begin{array}{l}\text { Cloud base } \\
\text { buoyancy }\end{array}$ \\
\hline $\begin{array}{l}\text { Center for Climate System } \\
\text { Research, National } \\
\text { Institute for } \\
\text { Environmental Studies, } \\
\text { and Frontier Research } \\
\text { Center for Global } \\
\text { Change }\end{array}$ & $\begin{array}{l}\text { MIROC3.2 } \\
\text { (hires) } \\
\text { (MIROC- } \\
\text { hires) }\end{array}$ & $\begin{array}{l}\text { Spectral/T106-L56/ } \\
\quad 40 \mathrm{~km}\end{array}$ & $\begin{array}{l}\text { Pan and Randall (1998)/ } \\
\text { Emori et al. (2001) }\end{array}$ & $\mathrm{Y} / \mathrm{N} / \mathrm{N}$ & $\begin{array}{l}\text { CAPE/relative } \\
\text { humidity }\end{array}$ \\
\hline Same as above & $\begin{array}{l}\text { MIROC3.2 } \\
\text { (medres) } \\
\text { (MIROC- } \\
\text { medres) }\end{array}$ & $\begin{array}{l}\text { Spectral/T42-L20/ } \\
\quad 30 \mathrm{~km}\end{array}$ & $\begin{array}{l}\text { Pan and Randall (1998)/ } \\
\text { Emori et al. (2001) }\end{array}$ & $\mathrm{Y} / \mathrm{N} / \mathrm{N}$ & $\begin{array}{l}\text { CAPE/relative } \\
\text { humidity }\end{array}$ \\
\hline $\begin{array}{l}\text { Meteorological Research } \\
\text { Institute }\end{array}$ & $\begin{array}{l}\text { MRI CGCM2.3.2 } \\
\text { (MRI) }\end{array}$ & $\begin{array}{l}\text { Spectral/T42-L30/ } \\
0.4 \mathrm{mb}\end{array}$ & Pan and Randall (1998) & $\mathrm{Y} / \mathrm{N} / \mathrm{N}$ & CAPE \\
\hline $\begin{array}{l}\text { Canadian Centre for } \\
\text { Climate Modelling and } \\
\text { Analysis }\end{array}$ & $\begin{array}{l}\text { CGCM3.1-T47 } \\
\text { (CGCM) }\end{array}$ & $\begin{array}{l}\text { Spectral/T47-L32/ } \\
\quad 1 \mathrm{mb}\end{array}$ & $\begin{array}{l}\text { Zhang and McFarlane } \\
\text { (1995) }\end{array}$ & $\mathrm{Y} / \mathrm{N} / \mathrm{N}$ & CAPE \\
\hline $\begin{array}{l}\text { Max Planck Institute for } \\
\text { Meteorology }\end{array}$ & $\begin{array}{l}\text { ECHAM5/MPI- } \\
\text { OM (MPI) }\end{array}$ & $\begin{array}{l}\text { Spectral/T63-L31/ } \\
10 \mathrm{mb}\end{array}$ & $\begin{array}{l}\text { Tiedtke }(1989) / \\
\text { Nordeng (1994) }\end{array}$ & $\mathrm{Y} / \mathrm{N} / \mathrm{N}$ & $\begin{array}{l}\mathrm{CAPE} / \text { moisture } \\
\text { convergence }\end{array}$ \\
\hline $\begin{array}{l}\text { Institute Pierre Simon } \\
\text { Laplace }\end{array}$ & $\begin{array}{l}\text { IPSL-CM4 } \\
\text { (IPSL) }\end{array}$ & $\begin{array}{l}\text { Gridpoint/96 × } 72 \\
\quad \text { L19 }\end{array}$ & Emanuel (1991) & $\mathrm{Y} / \mathrm{Y} / \mathrm{N}$ & CAPE \\
\hline $\begin{array}{l}\text { Mateo-France/Centre } \\
\text { National de Recherches } \\
\text { Météorologiques }\end{array}$ & $\begin{array}{l}\text { CNRM-CM3 } \\
\text { (CNRM) }\end{array}$ & $\begin{array}{l}\text { Spectral/T63-L45/ } \\
0.05 \mathrm{mb}\end{array}$ & Bougeault (1985) & $\mathrm{N} / \mathrm{N} / \mathrm{N}$ & $\begin{array}{l}\text { Moisture } \\
\text { convergence }\end{array}$ \\
\hline $\begin{array}{l}\text { CSIRO Atmospheric } \\
\text { Research }\end{array}$ & $\begin{array}{l}\text { CSIRO Mk3.0 } \\
\text { (CSIRO) }\end{array}$ & $\begin{array}{l}\text { Spectral/T63-L18/ } \\
\quad 4 \mathrm{mb}\end{array}$ & $\begin{array}{l}\text { Gregory and Rowntree } \\
\text { (1990) }\end{array}$ & $\mathrm{Y} / \mathrm{N} / \mathrm{N}$ & $\begin{array}{l}\text { Cloud-base } \\
\text { buoyancy }\end{array}$ \\
\hline
\end{tabular}

* For downdrafts, SC means saturated convective downdrafts, UC means unsaturated convective downdrafts, and meso means mesoscale downdrafts.

climate and different climate change scenarios in the twenty-first century. Before conducting the extended simulations, many of the modeling centers applied an overhaul to their physical schemes to incorporate the state-of-the-art research results. For example, almost all modeling centers have implemented prognostic cloud microphysics schemes to their models, some have added a moisture trigger to their deep convection schemes, and some now take into account convective momentum transport. Moreover, many modeling centers increased their models' horizontal and vertical resolutions and some conducted experiments with different resolutions. Some also did Atmospheric Model Intercomparison Project (AMIP) runs in addition to the standard coupled runs. Therefore, it is of interest to assess the simulations of tropical subseasonal variability in this new generation of climate models to look at the effects of the updated physical processes, higher resolution, and air-sea coupling. Such an evaluation is also important for evaluating the general performance of the climate models used for climate change projections in the IPCC AR4.

Lin et al. (2006) evaluated the Madden-Julian oscillation (MJO) and convectively coupled equatorial waves in 14 IPCC AR4 models. The results show that current state-of-the-art GCMs still have significant problems and display a wide range of skill in simulating tropical intraseasonal variability. The total intrasea- 

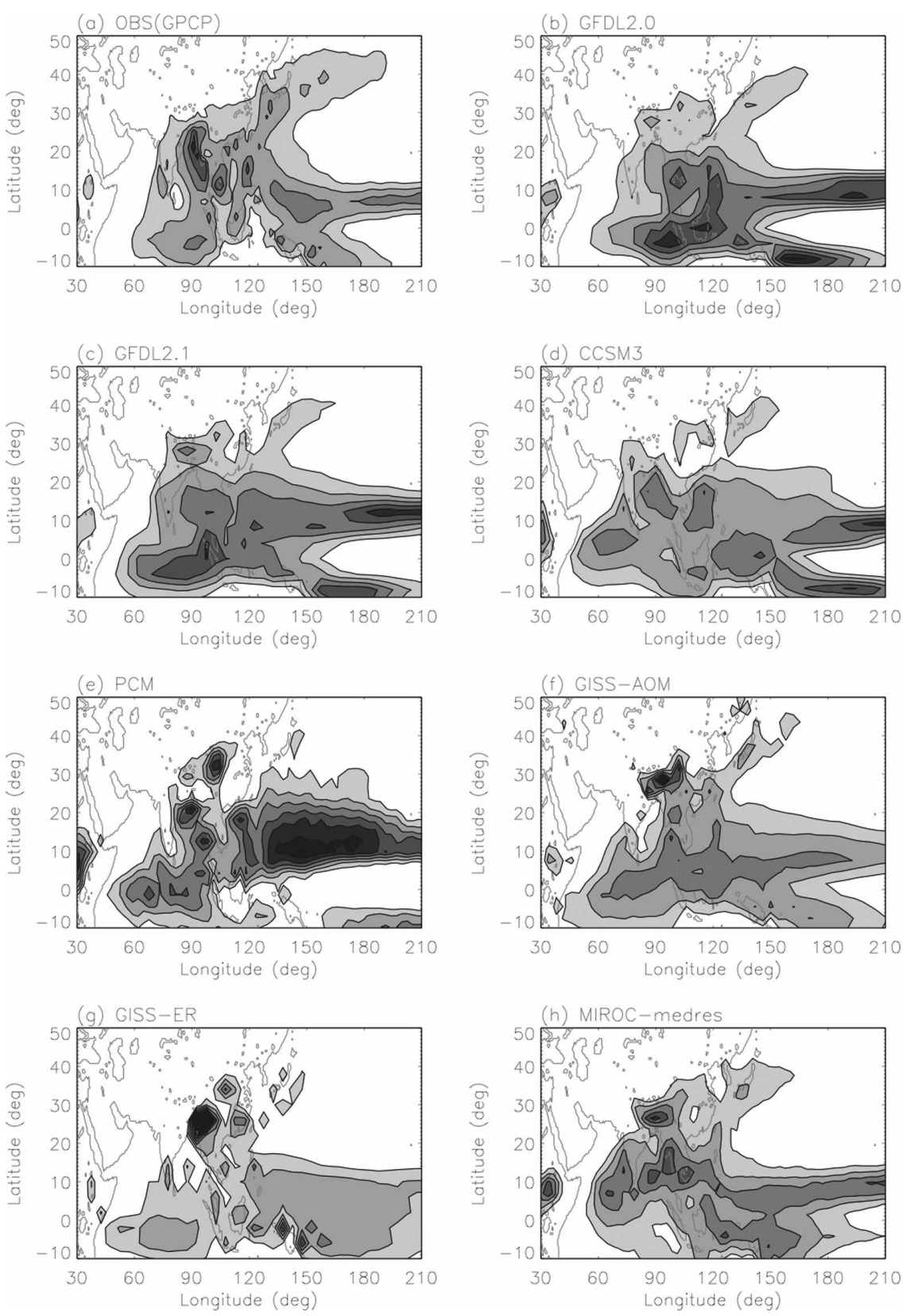

FIG. 2. Boreal summer (May-October) seasonal-mean precipitation for (a), (i) observations and (b)-(h), (j)-(p) 14 IPCC AR4 models. The first contour is $4 \mathrm{~mm}$ day $^{-1}$ and contour interval is $2 \mathrm{~mm} \mathrm{day}^{-1}$.

sonal variance of precipitation is too weak in most of the models. About half of the models have signals of convectively coupled equatorial waves, but the variances are generally too weak and the phase speeds are generally too fast, suggesting that the models may not have a large enough reduction in their "effective static stability" by diabatic heating. Most of the models produce overly weak MJO variance and poor MJO propagation. Moreover, the MJO variance in 13 of the 14 models does not come from a pronounced spectral peak, but usually comes from part of an overreddened spectrum, which in turn is associated with too strong persistence of equatorial precipitation. The two models that arguably do best at simulating the MJO are the only models having convective closures-triggers linked in some way to moisture convergence.

The purpose of this study is to extend the Lin et al. (2006) analysis to evaluate the subseasonal variability 

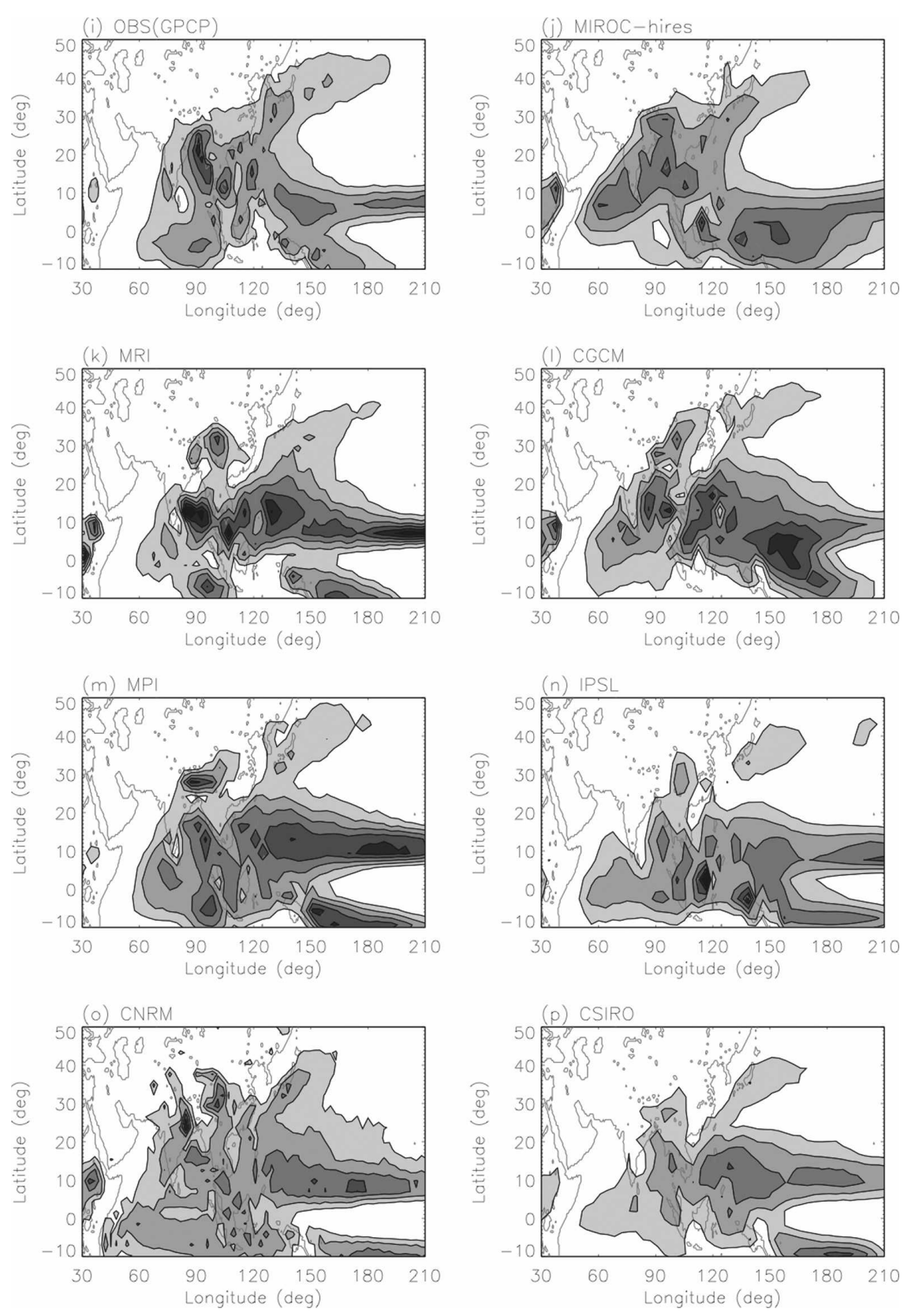

FIG. 2. (Continued)

associated with Asian summer monsoon in IPCC AR4 coupled GCMs, with an emphasis on the BSIO and 12-24-day mode. All the previous model intercomparison studies used atmospheric GCMs forced by observed SSTs (e.g., Sperber et al. 2001; Wu et al. 2002; Waliser et al. 2003a,b,c), and the present study, to our knowledge, is the first coupled GCM intercomparison in the literature for Asian summer monsoon subseasonal variability. If air-sea coupling does indeed significantly improve GCM's simulations of Asian summer monsoon subseasonal variability (e.g., Kemball-Cook et al. 2002; Fu and Wang 2004a,b), the coupled models should be expected to perform better. The questions we address are the following:

1) How well do the IPCC AR4 models simulate the subseasonal precipitation signals associated with Asian summer monsoon, especially the BSIO?

2) How well do the models simulate the divergence and humidity structures of BSIO, which have been 
suggested by theoretical studies to be important for the BSIO dynamics?

3 ) Is there any connection between the modelsimulated eastward component of BSIO and the simulated northward component of BSIO?

The models and validation datasets used in this study are described in section 2. The diagnostic methods are described in section 3. Results are presented in section 4. A summary and discussion are given in section 5 .

\section{Models and validation datasets}

This analysis is based on $8 \mathrm{yr}$ of the climate of the twentieth-century (20C3M) simulations from 14 coupled GCMs. Table 1 shows the model names and acronyms, their horizontal and vertical resolutions, and brief descriptions of their deep convection schemes. For each model we use $8 \mathrm{yr}$ of daily mean surface precipitation. Three-dimensional data are available for 7 of the 14 models, for which we analyzed upper air winds, temperature, and specific humidity.

The model simulations are validated using the Global Precipitation Climatology Project (GPCP) Version 2 Precipitation (Huffman et al. 2001). We use eight years (1997-2004) of daily data with a horizontal resolution of $1^{\circ}$ longitude by $1^{\circ}$ latitude.

\section{Method}

BSIO variability can be decomposed into two components: an eastward-propagating component and a northward-propagating component. The eastward component is defined as rainfall variability in eastward zonal wavenumbers 1-6 and in the period range of 2470 days, while the northward component is defined as northward-propagating 24-70-day variability which includes all meridional wavenumbers. As shown by previous observational studies (e.g., Fu et al. 2003), the northward component of BSIO is dominated by the largest meridional wavenumber within the latitude range of the analysis $\left(5^{\circ}-25^{\circ} \mathrm{N}\right)$. Therefore, although we include all meridional wavenumbers, the isolated signal is dominated by the largest wavenumber, as will be shown later in section $4 \mathrm{c}$.

The eastward component of BSIO is isolated using the following procedure: 1) The $8 \mathrm{yr}$ of daily precipitation data were averaged along the latitude belt between $5^{\circ}$ and $25^{\circ} \mathrm{N}$, where the eastward propagation of BSIO mainly happens, with a zonal resolution of $10^{\circ}$ longitude (all data were first linearly interpolated to a fine zonal resolution of $1^{\circ}$ longitude, and then averaged over each $10^{\circ}$ grid box). 2) The space-time spectrum was calculated using discrete Fourier transform for the whole 8-yr time series. 3) Then we used an inverse space-time Fourier transform to get the time series of the eastward wavenumbers 1-6 component, which includes all available frequencies. 4) These time series were filtered using a 365-point 24-70-day Lanczos filter (Duchan 1979). Because the Lanczos filter is nonrecursive, 182 days of data were lost at each end of the time series (364 days in total). 5) The resultant eastward wavenumbers 1 through 6, 24-70-day anomaly during northern summer (May-October) is hereafter referred to as the eastward component of the BSIO anomaly. 6) Its variance was also compared with the variance of its westward counterpart, that is, the westward wavenumbers 1-6, 24-70-day anomaly, which was isolated using the same method as above.

The northward component of BSIO was isolated using the same procedure as above except for the northward 24-70-day mode including all meridional wavenumbers, which is similar to the procedure in $\mathrm{Fu}$ and Wang (2004a,b). The space-time Fourier analysis was applied to the latitude range between $45^{\circ} \mathrm{S}$ and $45^{\circ} \mathrm{N}$. Although precipitation is very small at $45^{\circ} \mathrm{S}$ and $45^{\circ} \mathrm{N}$, we still tap the data to zero at each end to get a strict periodicity for this meridional section. The variance of the northward component of BSIO was averaged over two longitude belts: $70^{\circ}-100^{\circ} \mathrm{E}$ (the ISM region) and $120^{\circ}-160^{\circ} \mathrm{E}$ (the WNPSM and EASM regions). It was also compared with the variance of its southward counterpart, that is, the southward 24-70-day anomaly, which was isolated using the same method as above.

The procedure for isolating the 12-24-day mode is also same as above except for the westward 12-24-day mode including all zonal wavenumbers. Its variance was also compared with the variance of its eastward counterpart, that is, the eastward 12-24-day anomaly, which was isolated using the same method as above.

\section{Results}

\section{a. Boreal summer (May-October) seasonal-mean precipitation and seasonal variation}

Previous observational studies indicate that the subseasonal variance of convection is highly correlated with time-mean convective intensity (e.g., Wheeler and Kiladis 1999). Therefore, we first look at the horizontal distribution of boreal summer (May-October) seasonal-mean precipitation (Fig. 2). If we use the $4 \mathrm{~mm}$ day $^{-1}$ contour to define the gross horizontal pattern of precipitation in observation, 12 of the 14 models capture this pattern reasonably well (GFDL2.0, GFDL2.1, CCSM3, GISS-AOM, MIROC-medres, MIROC-hires, 


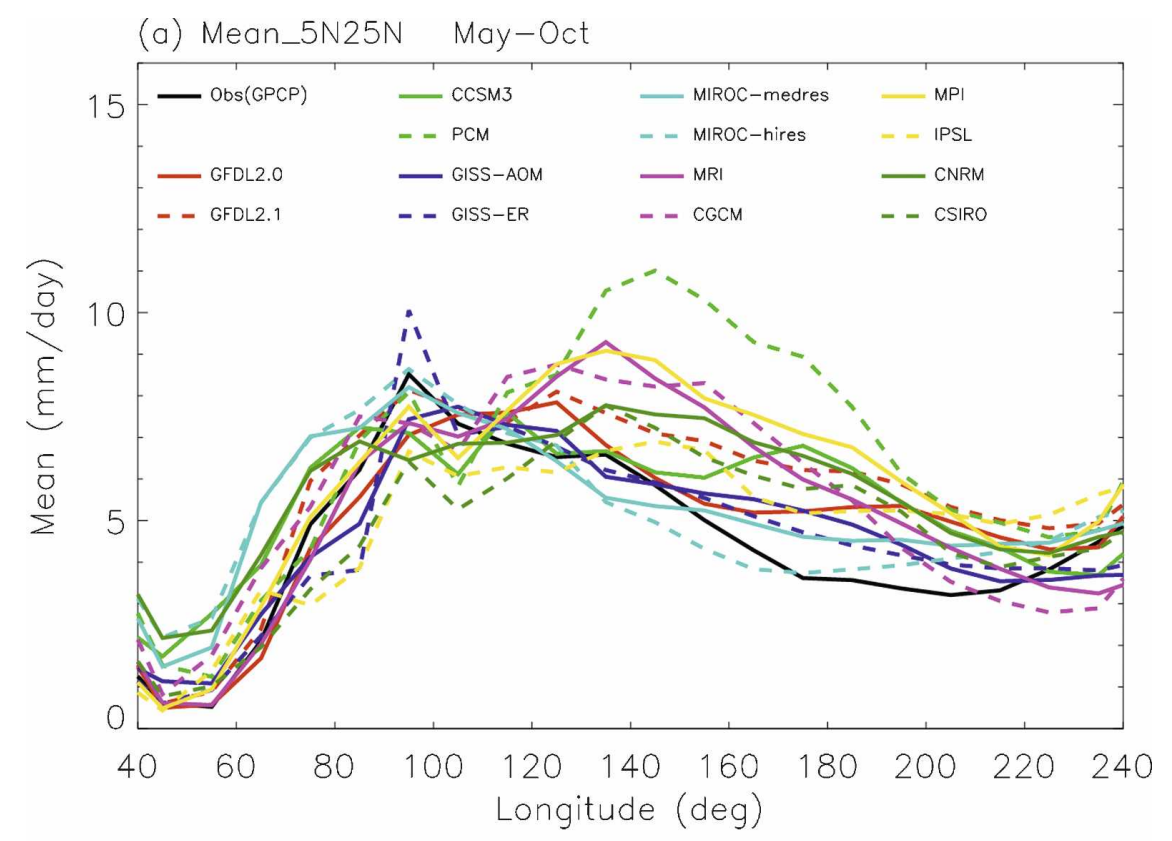

(b) Mean_25N40N May-Oct

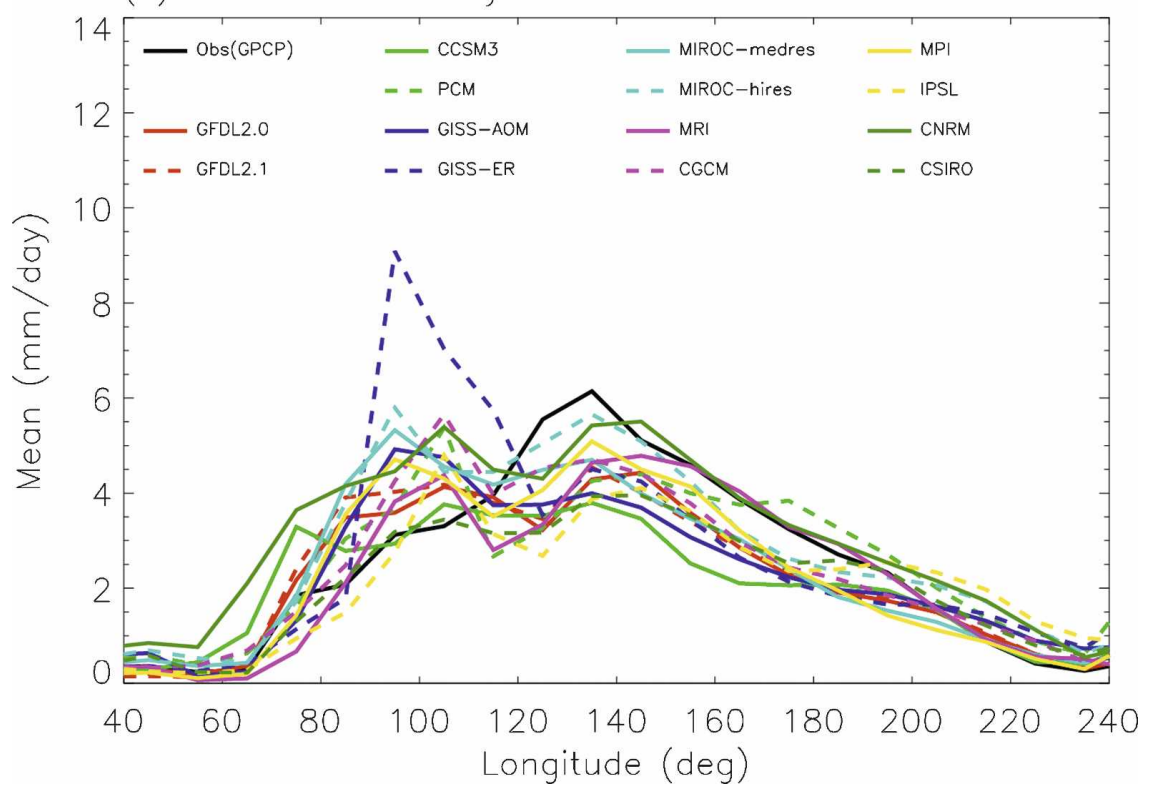

FIG. 3. Zonal profile of boreal summer (May-October) seasonal-mean precipitation averaged

(a) between $5^{\circ}$ and $25^{\circ} \mathrm{N}$, and (b) between $25^{\circ}$ and $40^{\circ} \mathrm{N}$ for observations and 14 models.

MRI, CGCM, MPI, IPSL, CNRM, and CSIRO). In particular, they all produce the NE-SW-tilted Mei-YuBaiyu rainbelt. Most of them also capture the peak in the Bay of Bengal-Bangladesh region. GISS-ER and PCM have difficulties in simulating the Mei-Yu-Baiyu rainbelt, with $\mathrm{PCM}$ producing too much rain in the WNPSM region.

Next we conduct a more quantitative evaluation in the three components of Asian summer monsoon: the
ISM region, the EASM region, and the WNPSM region (Fig. 1). Figure 3a shows the zonal profile along the latitude belt averaged between $5^{\circ}$ and $25^{\circ} \mathrm{N}$. Most of the models produce reasonable seasonal-mean precipitation in the ISM region $\left(60^{\circ}-100^{\circ} \mathrm{E}\right)$, but overly large precipitation in the WNPSM region $\left(110^{\circ}-170^{\circ} \mathrm{E}\right)$, which is associated with an overall overestimate of precipitation along the Pacific ITCZ (Lin 2007). Figure 3b shows the zonal profile averaged between $25^{\circ}$ and 

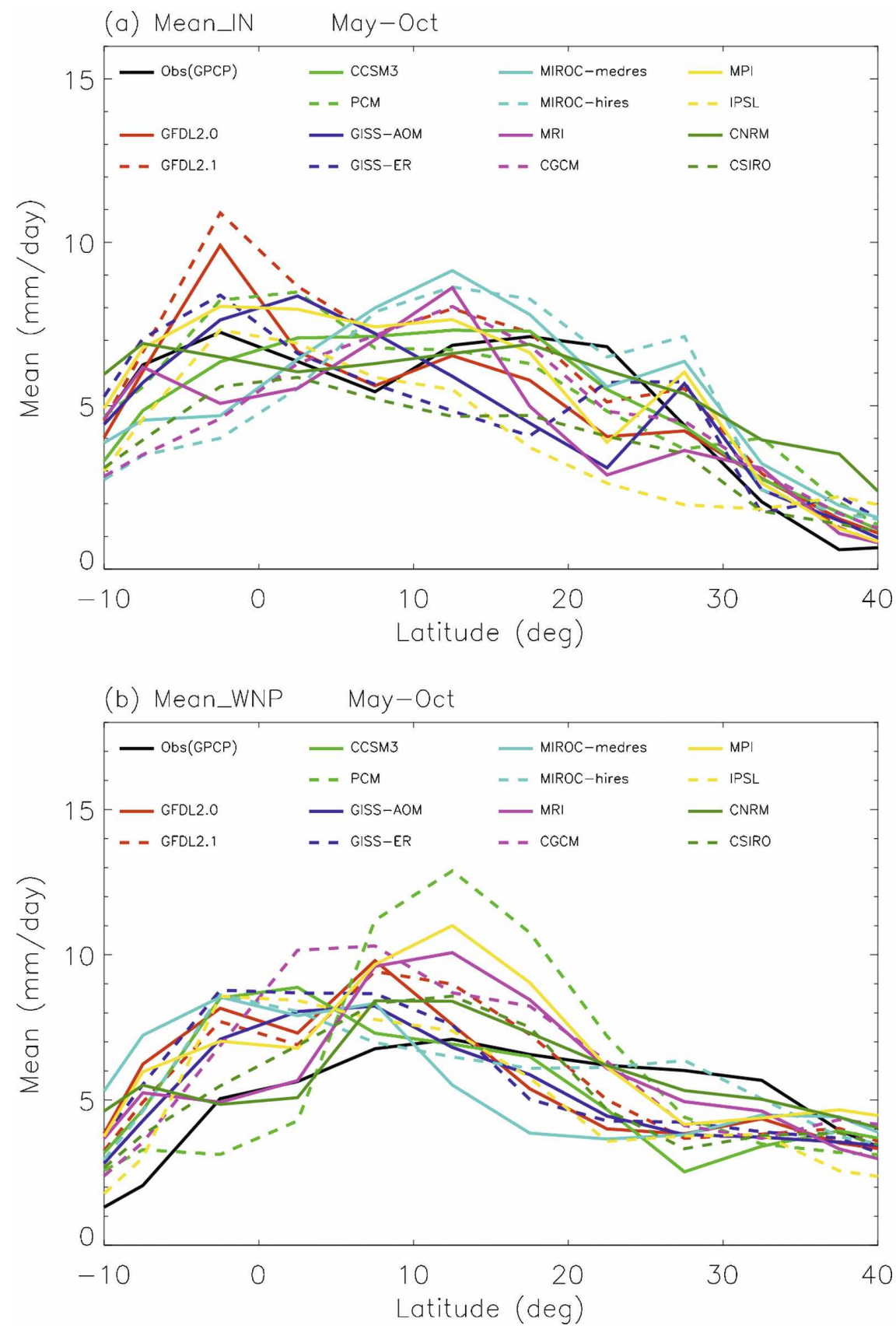

FIG. 4. Same as Fig. 3, but for the meridional profile averaged (a) between $70^{\circ}$ and $100^{\circ} \mathrm{E}$, and (b) between $120^{\circ}$ and $160^{\circ} \mathrm{E}$.

$40^{\circ} \mathrm{N}$. All models invariably underestimate the seasonal-mean precipitation in the EASM region $\left(100^{\circ}-\right.$ $\left.160^{\circ} \mathrm{E}\right)$.

To look at the detailed meridional distribution, we plot in Fig. 4a the meridional profile averaged between $60^{\circ}$ and $100^{\circ} \mathrm{E}$ (the ISM region). In observation the maximum precipitation in the Northern Hemisphere lies between $12^{\circ}$ and $22^{\circ} \mathrm{N}$, but in many models the maximum lies closer to the equator around $12^{\circ} \mathrm{N}$. The reasonable area-mean precipitation for the ISM region in many models (Fig. 3a) actually comes from compensation between excessive precipitation close to the equator and insufficient precipitation far from the equator. This problem is even more prominent in the meridional profile averaged between $100^{\circ}$ and $160^{\circ} \mathrm{E}$ (Fig. 4b), leading to the excessive precipitation over the 


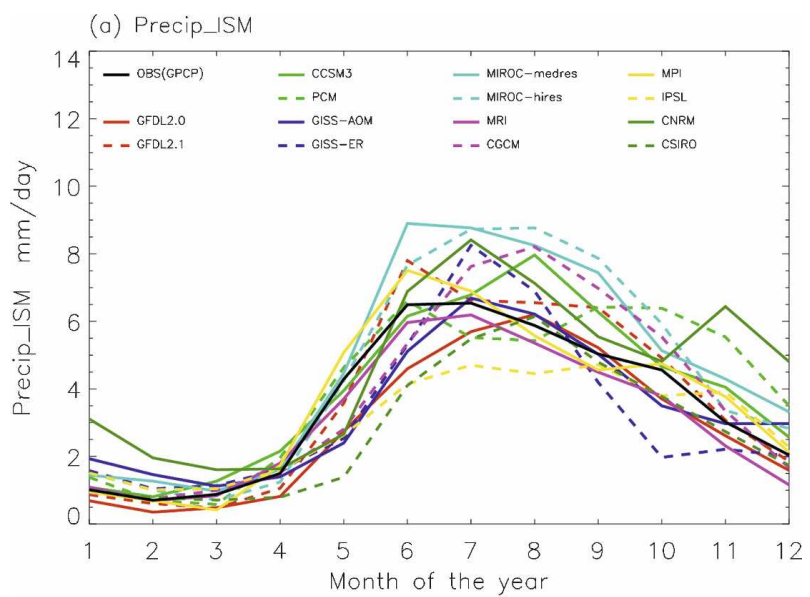

(b) Precip_WNPSM

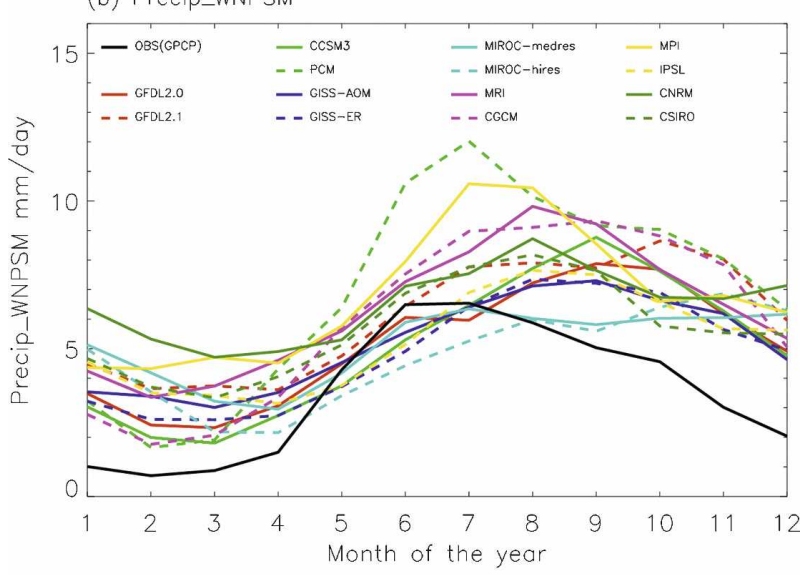

(c) Precip_EASM

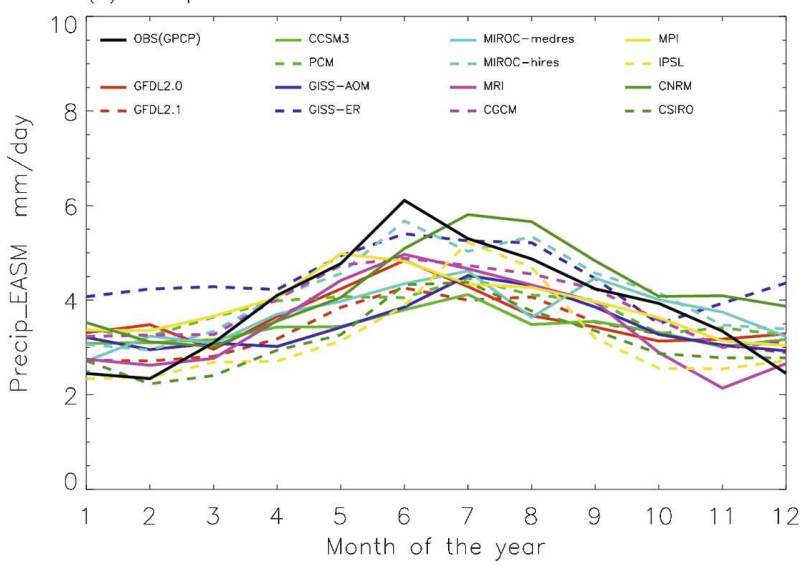

FIG. 5. Seasonal variation of precipitation averaged over (a) ISM region $\left(5^{\circ}-25^{\circ} \mathrm{N}, 60^{\circ}-100^{\circ} \mathrm{E}\right)$, (b) WNPSM region $\left(5^{\circ}-25^{\circ} \mathrm{N}\right.$, $\left.110^{\circ}-170^{\circ} \mathrm{E}\right)$, and (c) EASM region $\left(25^{\circ}-40^{\circ} \mathrm{N}, 100^{\circ}-160^{\circ} \mathrm{E}\right)$ for observations and 14 models.

WNPSM region $\left(5^{\circ}-25^{\circ} \mathrm{N}\right)$ but insufficient precipitation over the EASM region $\left(25^{\circ}-40^{\circ} \mathrm{N}\right)$.

Figure 5 shows the seasonal cycle of precipitation averaged over the three monsoon regions. For the ISM region (Fig. 5a), most of the models reproduce the monsoon onset in May. However, many models tend to produce excessive precipitation from July to September (e.g., MIROC-medres, MIROC-hires, CNRM, CCSM3, and CGCM). For the WNPSM region (Fig. 5b), most of the models simulate well the phase of seasonal cycle, but produce excessive precipitation throughout the whole seasonal cycle. For the EASM region (Fig. 5c), most of the models do not have significant seasonal variation, with insufficient precipitation during summer but excessive precipitation during winter.

In summary, most of the IPCC AR4 climate models produce reasonable seasonal-mean precipitation over the ISM region, but excessive precipitation over the WNPSM region and insufficient precipitation over the EASM region. Models tend to produce excessive precipitation close to the equator but insufficient precipitation far from the equator. Most of the models reproduce well the phase of seasonal cycle in the ISM and WNPSM regions, but produce too-weak seasonal variation in the EASM region.

\section{b. Total subseasonal (2-128 day) variance and spectrum}

Figure 6 shows the horizontal distribution of the standard deviation of total subseasonal (2-128 day) precipitation anomaly during northern summer (MayOctober). We have tried some narrower frequency bands (e.g., 20-90 day) and the results look similar. The observed precipitation variability has three maxima: the Bay of Bengal-Bangladesh region, South China Sea, and equatorial Indian Ocean. In terms of the overall magnitude of the precipitation variability, at least 9 of the 14 models underestimate the variability (GFDL2.0, GFDL2.1, CCSM3, PCM, GISS-AOM, GISS-ER, MIROC-hires, IPSL, and CSIRO). Moreover, at least four models have the largest variability closer to the equator than in observation (GFDL2.0, GFDL2.1, MIROC-medres, and IPSL). About three models (MIROC-medres, MPI, and CNRM) produce nearly realistic magnitude and reasonable horizontal pattern. Figure 6 can be compared with the AGCM simulations of Waliser et al. (2003c, their Fig. 3). Among the 10 AGCMs studied by Waliser et al. (2003c), about half tend to overestimate the total subseasonal variance. On the contrary, the IPCC coupled GCMs tend to underestimate the total subseasonal variance.

To provide a more quantitative evaluation of the model simulations, Fig. 7a shows the meridional profile of total subseasonal (2-128 day) variance of precipitation in the ISM region averaged between $60^{\circ}$ and $100^{\circ} \mathrm{E}$. The observed variance shows two peaks: one in 

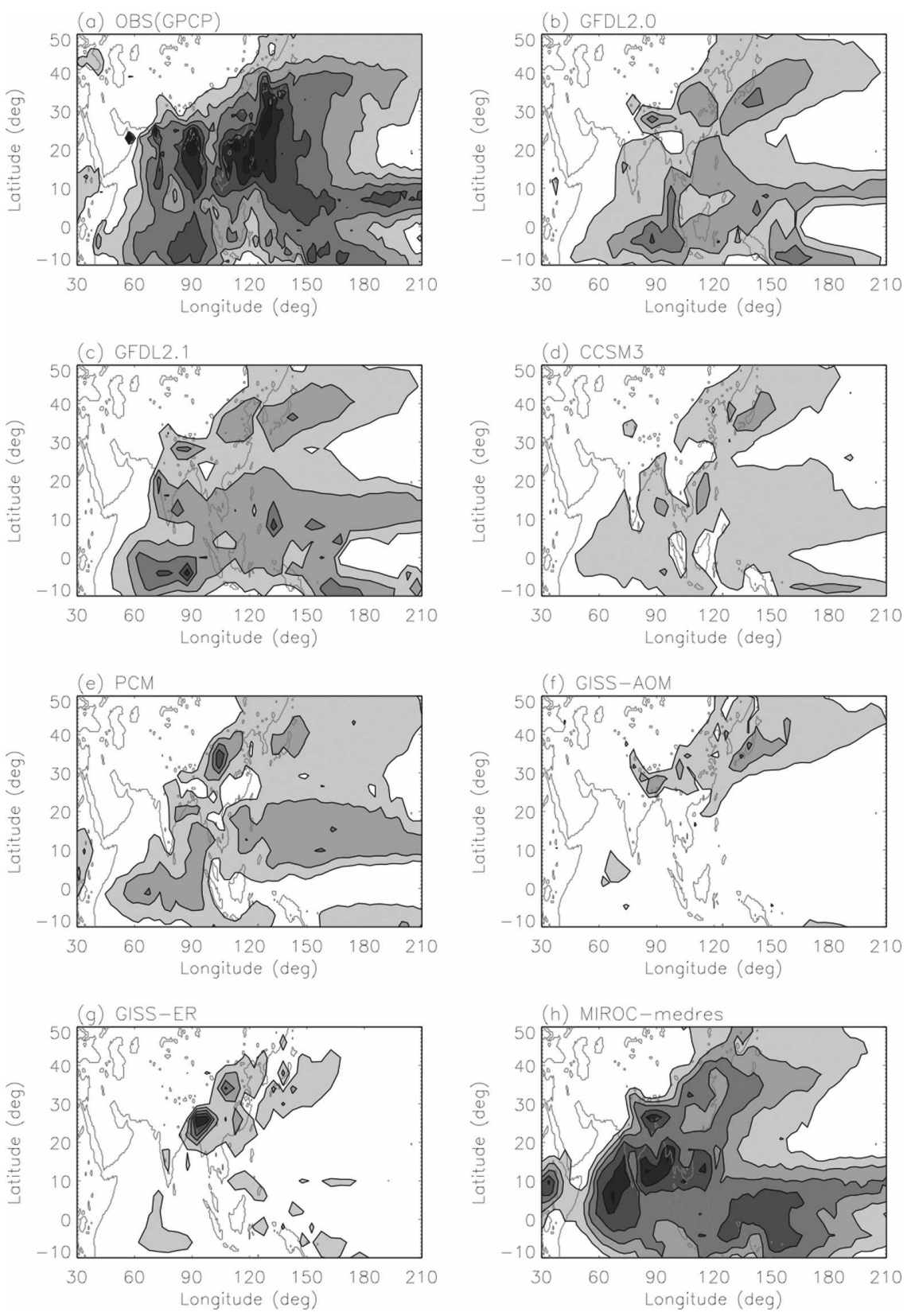

FIG. 6. Horizontal distribution of the std dev of total subseasonal (2-128 day) precipitation anomaly during northern summer (May-October): (a), (i) observations and (b)-(h), (j)-(p) 14 IPCC AR4 models. The first contour is $4 \mathrm{~mm}^{\text {day }}{ }^{-1}$ and the contour interval is $2 \mathrm{~mm} \mathrm{day}{ }^{-1}$.

the ISM region and the other on the equator, with the equatorial region possessing larger variance. The total subseasonal variance in most of the models is smaller than in observation. The variance in three models [ECHAM5/ MPI-OM, MIROC3.2(medres), and MIROC3.2(hires)] approaches the observed value in the ISM region $\left(5^{\circ}-25^{\circ} \mathrm{N}\right)$. However, MIROC3.2(medres) and MIROC3.2(hires) produce too-weak variability on the equator in contrast with their strong variability in the ISM region. This is likely connected with their overly small seasonal-mean precipitation on the equator (Fig. 4a).

Figure $7 \mathrm{~b}$ shows the total subseasonal variance in the WNPSM and EASM regions (the region of longitudes chosen in Fig. 7b lies within the WNPSM and EASM boxes of Fig. 1). Again, most of the models produce overly small variances in both regions. Only one model (ECHAM5/MPI-OM) produces realistic variance in the WNPSM region $\left(5^{\circ}-25^{\circ} \mathrm{N}\right)$, and one model 

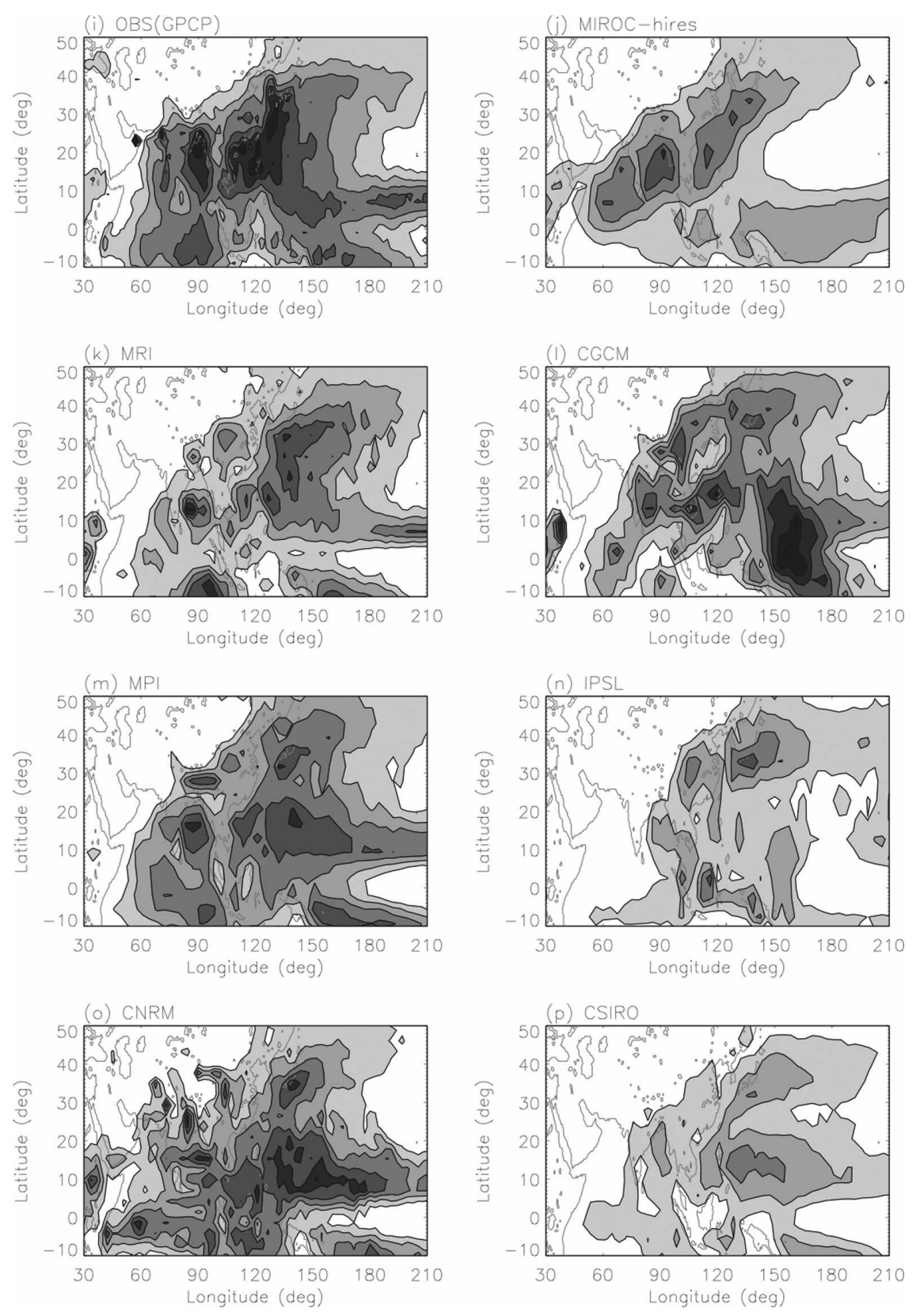

FIG. 6. (Continued)

[MIROC3.2(hires)] produces relatively large variance in the EASM region $\left(25^{\circ}-40^{\circ} \mathrm{N}\right)$.

It is interesting to note that the models with overly weak total subseasonal variance in both the ISM and WNPSM regions generally produce reasonable seasonalmean precipitation in the ISM region (Fig. 4a), and even excessive precipitation in the WNPSM region (Fig. 4b). Therefore, their insufficient subseasonal variability is not caused by insufficient seasonal-mean precipitation, and a good seasonal-mean simulation does not warrant a realistic simulation of the subseasonal variability.
Next we apply more detailed scrutiny to the subseasonal variability of Asian monsoon precipitation by looking at the shape of the temporal power spectrum. Figure 8a shows the normalized spectra at $15^{\circ} \mathrm{N}, 115^{\circ} \mathrm{E}$ (within the WNPSM region). The observational data show prominent spectral peaks in both the 24-70-day frequency band, which correspond to BSIO, and the 12-24-day frequency band, which correspond to the 1224-day mode. Only 4-5 models produce spectral peaks in both frequency bands (e.g., MIROC-medres, MPI, CNRM, and GFDL2.0), but most of them show too 

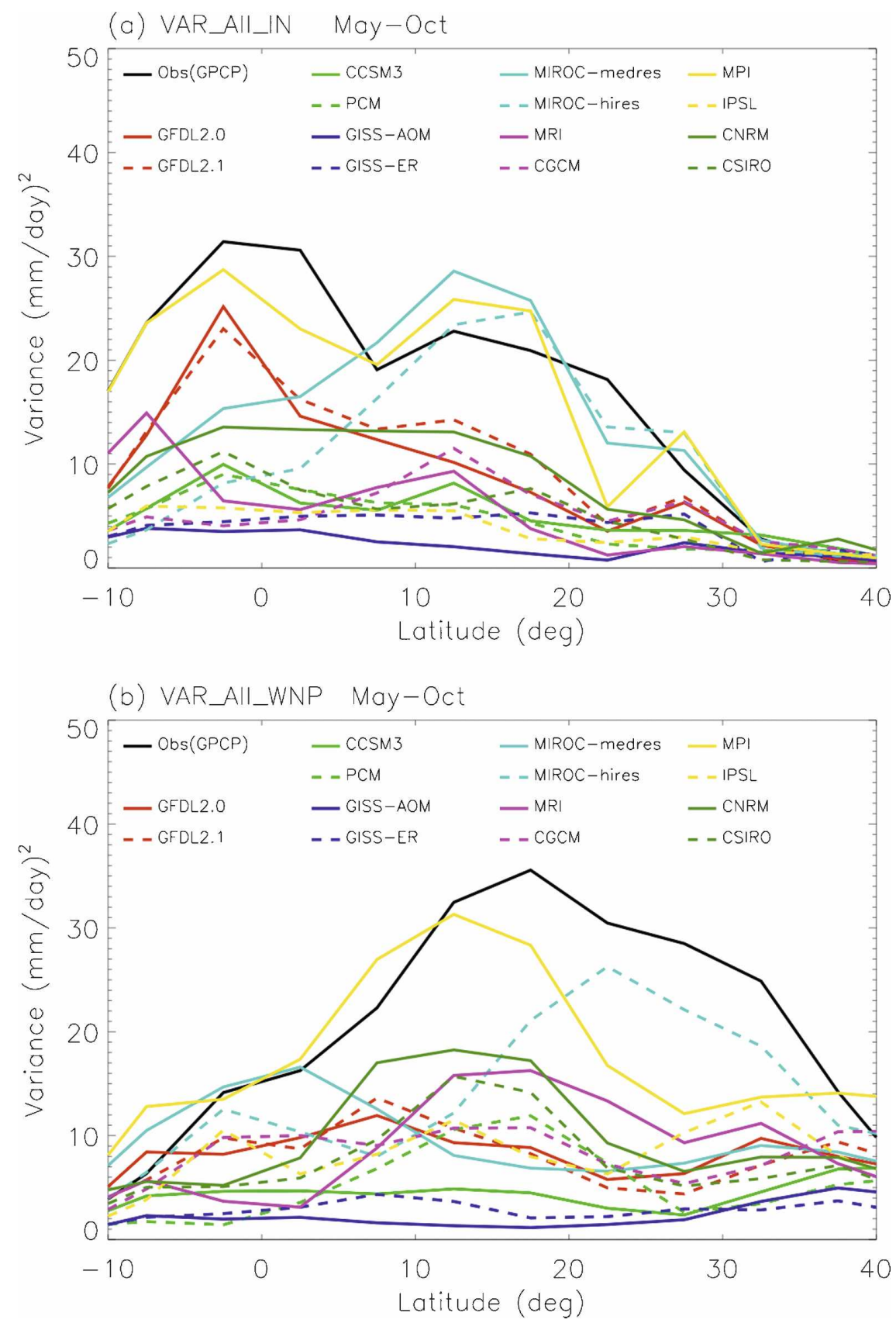

FIG. 7. Meridional profile of the total subseasonal (2-128 day) variance of precipitation anomaly averaged (a) between $60^{\circ}$ and $100^{\circ} \mathrm{E}$, and (b) between $120^{\circ}$ and $160^{\circ} \mathrm{E}$ for observations and 14 models.

much variance at periods longer than 70 days, that is, the spectrum is too red. Most of the other models without prominent spectral peak also display a too-red spectrum. The model spectra at $32^{\circ} \mathrm{N}, 115^{\circ} \mathrm{E}$ (Fig. $8 \mathrm{~b}$; within the EASM region) are even worse than at $15^{\circ} \mathrm{N}, 115^{\circ} \mathrm{E}$. Most of the models fail to produce the spectral peaks for either the BSIO or the 12-24-day mode, but display an overly reddened spectrum. These overly reddened spectra are associated with overly large lag 1 autocorrelation (persistence) of model precipitation (not shown), which is consistent with the results of Lin et al. (2006).

In summary, the total subseasonal (2-128 day) variance of precipitation in most models is smaller than in observations. Only a couple of models simulate realistic variance in one or two of the monsoon regions, but no 


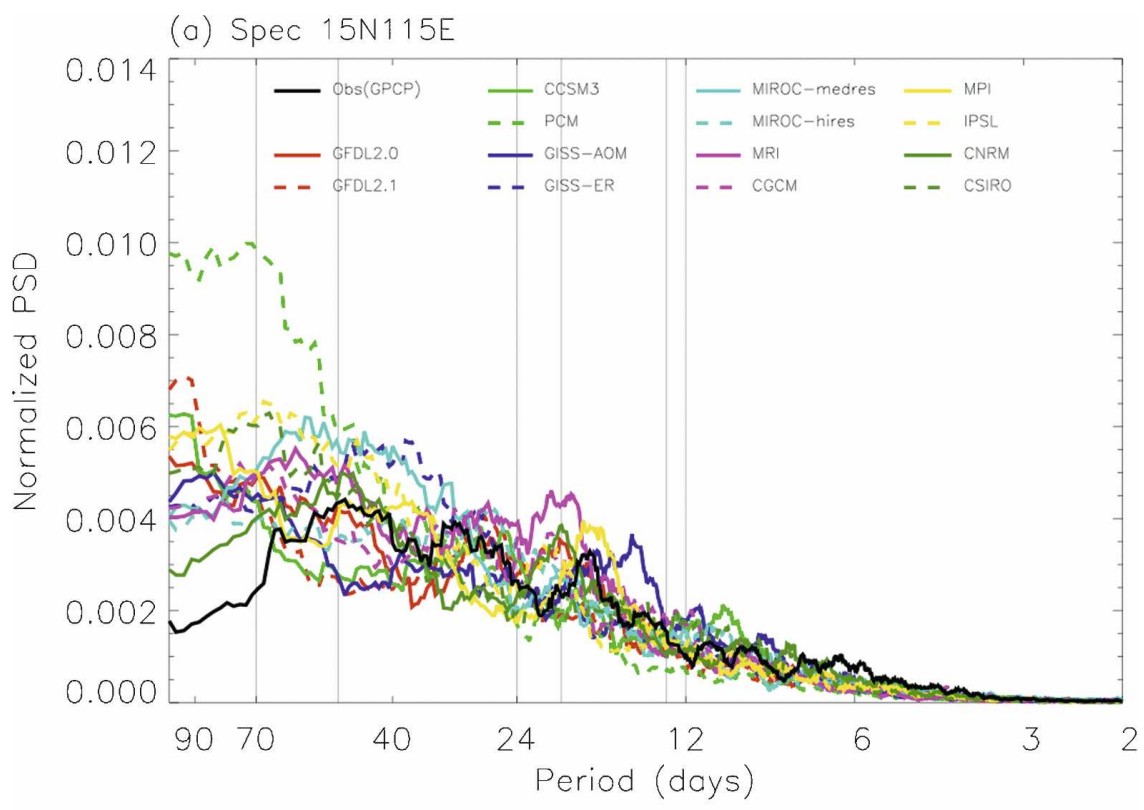

(b) Spec 32N115E

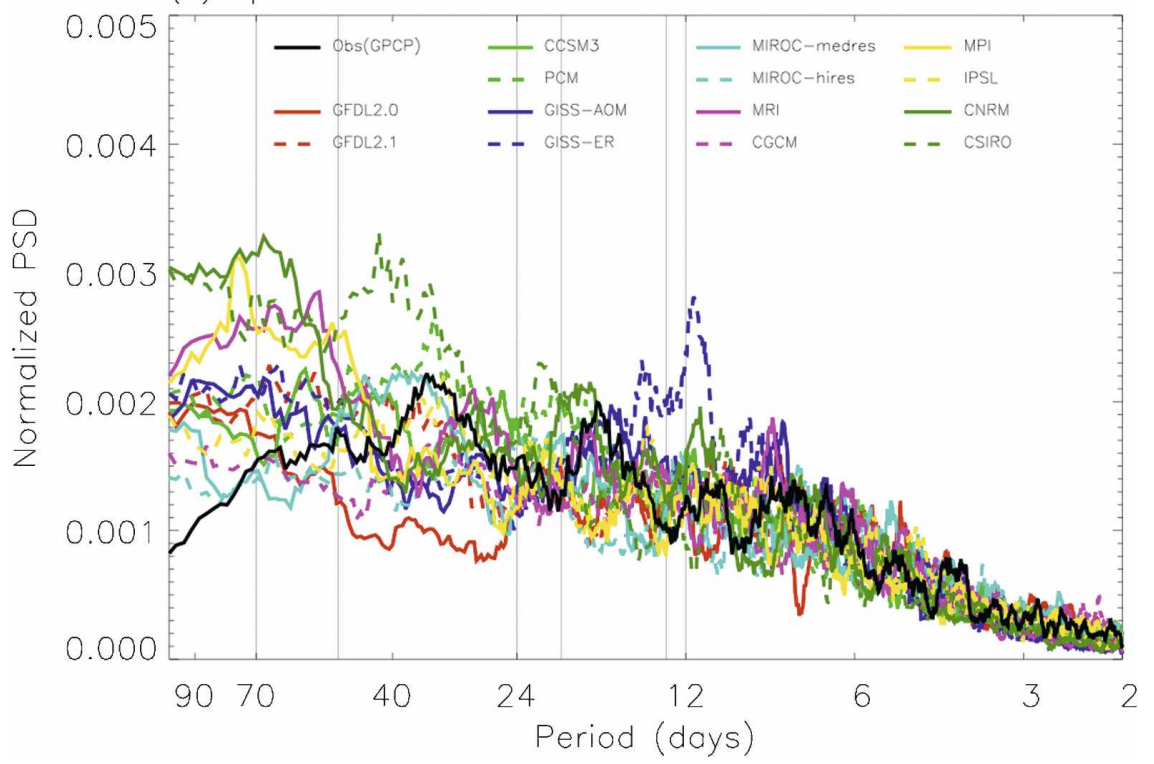

FIG. 8. Normalized spectrum of precipitation at (a) $15^{\circ} \mathrm{N}, 115^{\circ} \mathrm{E}$, and (b) $32^{\circ} \mathrm{N}, 115^{\circ} \mathrm{E}$ for observational data and 14 models. Frequency spectral width is $1 / 100 \mathrm{cpd}$.

model can reproduce the observed values in all three monsoon regions. Only 4-5 models produce spectral peaks for the BSIO and 12-24-day mode, while most of the models display too red a spectrum, which is consistent with the overly strong persistence of precipitation in those models.

\section{c. The eastward component of BSIO}

Now we focus on the variance of the eastward component of BSIO (hereafter BSIO-E), that is, the daily variance of the eastward wavenumbers 1-6, 24-70-day mode. Figure 9 shows the variance of BSIO-E along the equator averaged between $5^{\circ}$ and $25^{\circ} \mathrm{N}$. In observation the BSIO-E variance has its maximum over the Indian Ocean, but many models produce the largest variance over the Maritime Continent or western Pacific, which may be associated with the excessive seasonal-mean precipitation over the WNPSM region in many models (Fig. 3a). The model variance approaches the observed value in 3 of the 14 models over the WNPSM region 


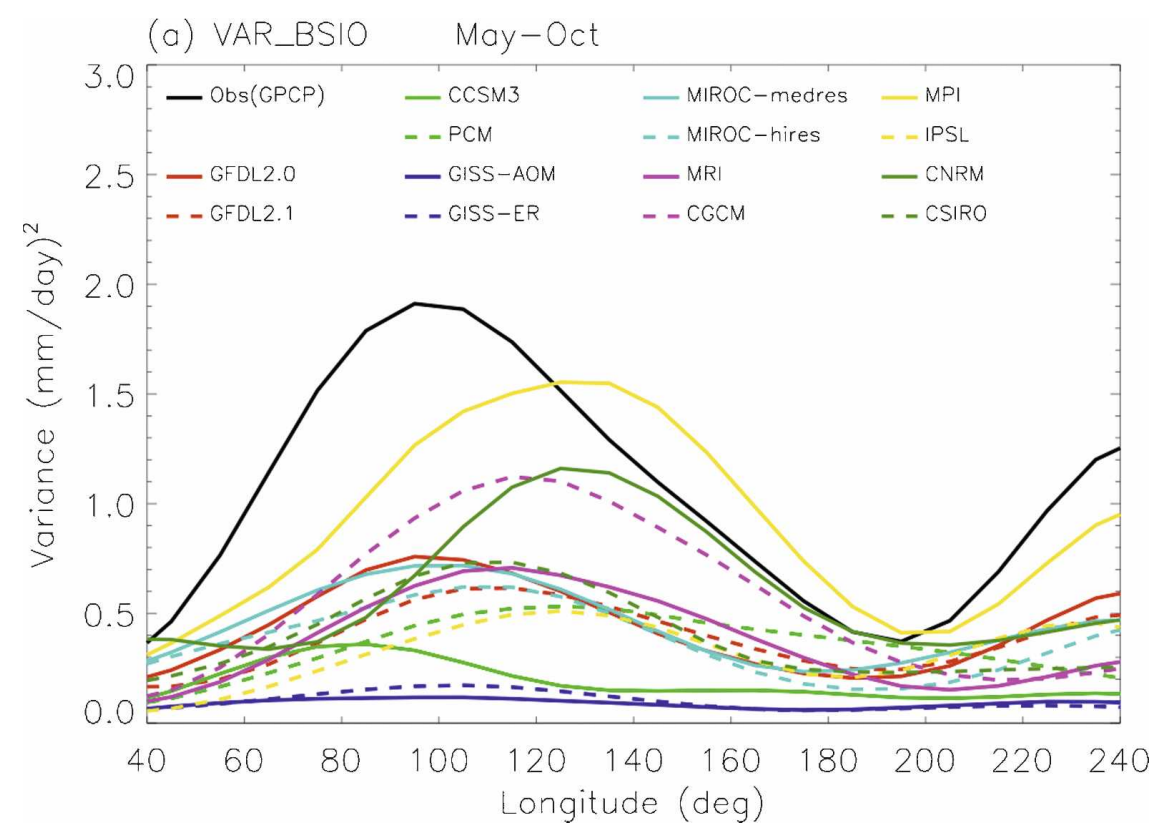

FIG. 9. Variance of the eastward component of BSIO averaged between $5^{\circ}$ and $25^{\circ} \mathrm{N}$ for observations and 14 models.

(ECHAM5/MPI-OM, CNRM, and CGCM), but is less than half of the observed value in all other 11 models. This is similar to the performance of the IPCC AR4 models in simulating the MJO (Lin et al. 2006), for which the simulated variance is less than half of the observed value in 12 of the 14 models.

In addition to the variance, another important index for evaluating the BSIO-E simulation is the ratio between the variance of the eastward BSIO-E and that of its westward counterpart, that is, the westward wavenumbers 1-6, 24-70-day mode, which is for a measure of the zonal propagation of tropical intraseasonal oscillation. Figure 10 shows the ratio between the eastward variance and the westward variance averaged over an Indian Ocean box between $5^{\circ}-25^{\circ} \mathrm{N}$ and $70^{\circ}-130^{\circ} \mathrm{E}$. In observation, the eastward BSIO-E variance is about 1.5 times of the westward variance. Of the 14 models, four models simulate a realistic or too-large ratio (GFDL2.0, PCM, CGCM, and CSIRO), but all other 10 models produce a too-small ratio that is nearly equal to one, or even less than one (i.e., westward variance dominates over eastward variance).

The competition between the eastward BSIO-E variance and its westward counterpart largely determines the zonal propagation characteristics of tropical intraseasonal oscillation. When the eastward BSIO-E variance is larger than its westward counterpart, the tropical intraseasonal oscillation events tend to have more eastward events than westward events, as is the case in observations. Figure 11 shows the lag correla- tion of the 24-70-day precipitation anomaly averaged between $5^{\circ}$ and $25^{\circ} \mathrm{N}$ with respect to itself at $15^{\circ} \mathrm{N}$, $95^{\circ} \mathrm{E}$. The observational data shows prominent eastward-propagating signals of the BSIO-E, with a phase speed of about $5 \mathrm{~m} \mathrm{~s}^{-1}$. The models display a wide range of propagation characteristics that are consistent with the ratio between the eastward BSIO-E variance and its westward counterpart shown in Fig. 10. The four models with a realistic or too-large ratio (GFDL2.0, PCM, CGCM, and CSIRO) show a highly coherent eastward-propagating signal. The phase speed is realistic in GFDL2.0, but is too slow in PCM, CGCM, and CSIRO. In addition, the motion often fails to pass the Maritime Continent (e.g., GFDL2.0, CCSM3). This is consistent with previous studies on coupled models (e.g., Inness and Slingo 2003). Other IPCC AR4 models with the eastward/westward ratio nearly equal to one or less than one show a standing oscillation (e.g., GFDL2.1, GISS-AOM) or westward propagation (e.g., MIROC-medres, MIROC-hires).

Next we look at the vertical structures of humidity and divergence, which have been emphasized by theoretical studies to be important for the dynamics of the tropical intraseasonal oscillation. Previous observational studies of tropical intraseasonal oscillation have found that the humidity has a westward phase tilt with height with low-level premoistening starting from lag -20 to -10 days (e.g., Kiladis et al. 2005, their Fig. 10). Theoretical models demonstrated that this moisture preconditioning plays a significant role in prolonging 


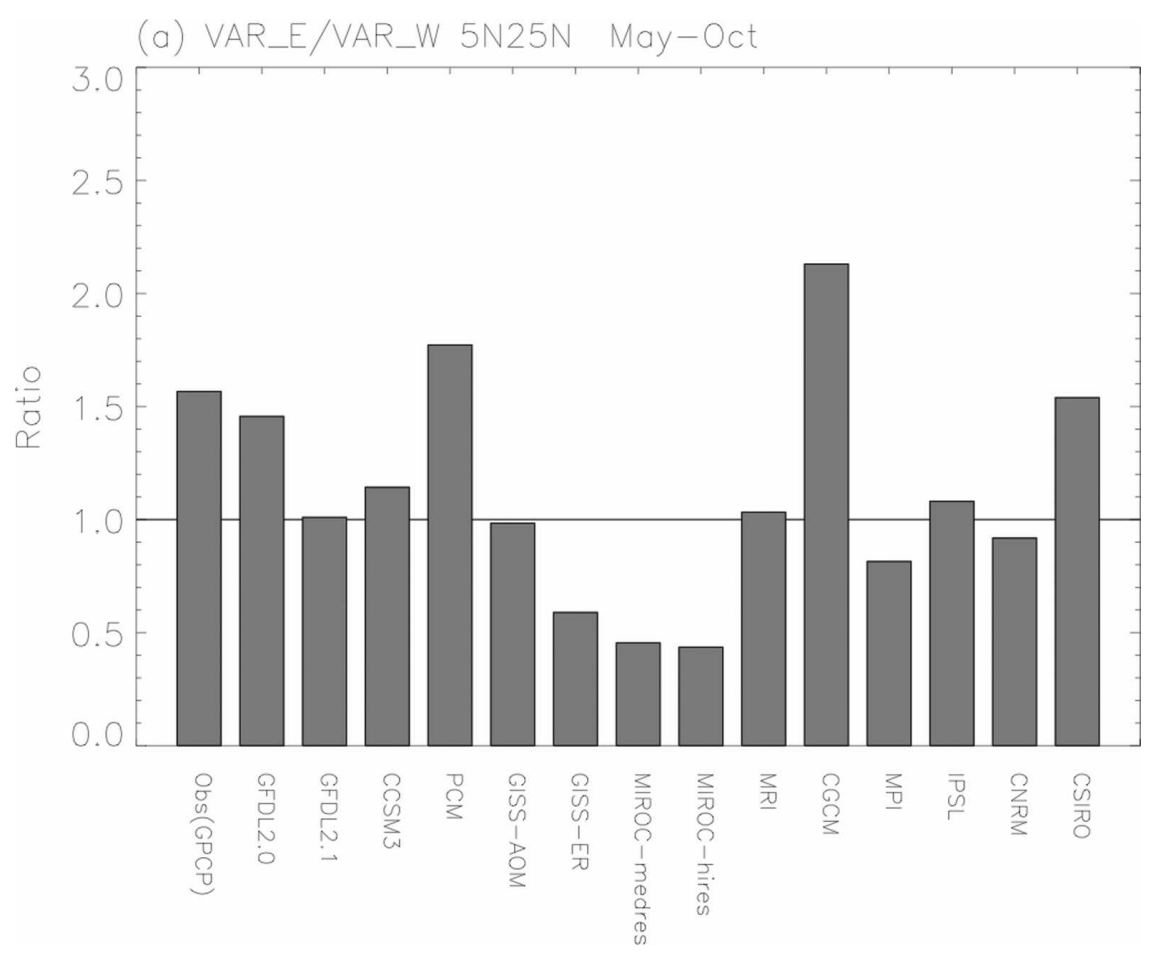

FIG. 10. Ratio between the variance of the eastward component of BSIO and the variance of its westward counterpart (westward wavenumbers 1-6, 24-70-day mode) for observations and 14 models. The variances are averaged over an Indian Ocean box between $5^{\circ}-25^{\circ} \mathrm{N}$ and $70^{\circ}-130^{\circ} \mathrm{E}$.

the period of the tropical intraseasonal oscillation, which is often referred to as the charge-discharge theory (e.g., Blade and Hartmann 1993; Hayashi and Golder 1997; Raymond 2001; Khouider and Majda 2006). Figure 12 shows the GCM-simulated humidity structure for seven IPCC models with three-dimensional data available. Five of the seven models (GFDL2.0, GFDL2.1, MRI, MPI, and CNRM) reproduce a westward phase tilt with height for humidity with low-level premoistening starting from lag -10 days. The premoistening generally starts about 10 days later than in observation, suggesting that in the models moisture is too easy to be transported from the boundary layer to the free troposphere. Some modifications need to be made to slow down the vertical transport processes and prolong the premoistening stage, which may help to prolong the BSIO period.

Many observational studies have found evidence of low-level convergence leading convection in tropical intraseasonal oscillation as it propagated eastward, and pronounced vertical tilts in divergence (e.g., Rui and Wang 1990; Lin et al. 2004; Kiladis et al. 2005). Theoretical studies showed that the phase lead of low-level convergence acts to amplify and slow down the tropical intraseasonal oscillation, which is often referred to as the frictional wave- conditional instability of the second kind (CISK) theory (Wang and Rui 1990; Salby et al. 1994; Moskowitz and Bretherton 2000). Figure 13 shows the GCM-simulated divergence structure. Only three models (GFDL2.1, MPI, and CNRM) simulate the phase lead of low-level convergence and westward phase tilt with height. Interestingly, MPI and CNRM are among the models with the largest BSIO-E variances.

To summarize, the model BSIO-E variance approaches the observed value over the Maritime Continent/western Pacific in 3 of the 14 models, but is less than half of the observed value in the other 11 models. The ratio between the eastward BSIO-E variance and its westward counterpart is too small in most of the models, which is consistent with the lack of highly coherent eastward propagation of the BSIO in many models. For the seven models with three-dimensional data available, five reproduce the preconditioning of moisture, which is important for the charge-discharge mechanism, but often with a too-late starting time. Only three of the seven models reproduce the phase lead of low-level convergence, which is important for the frictional wave-CISK mechanism. 

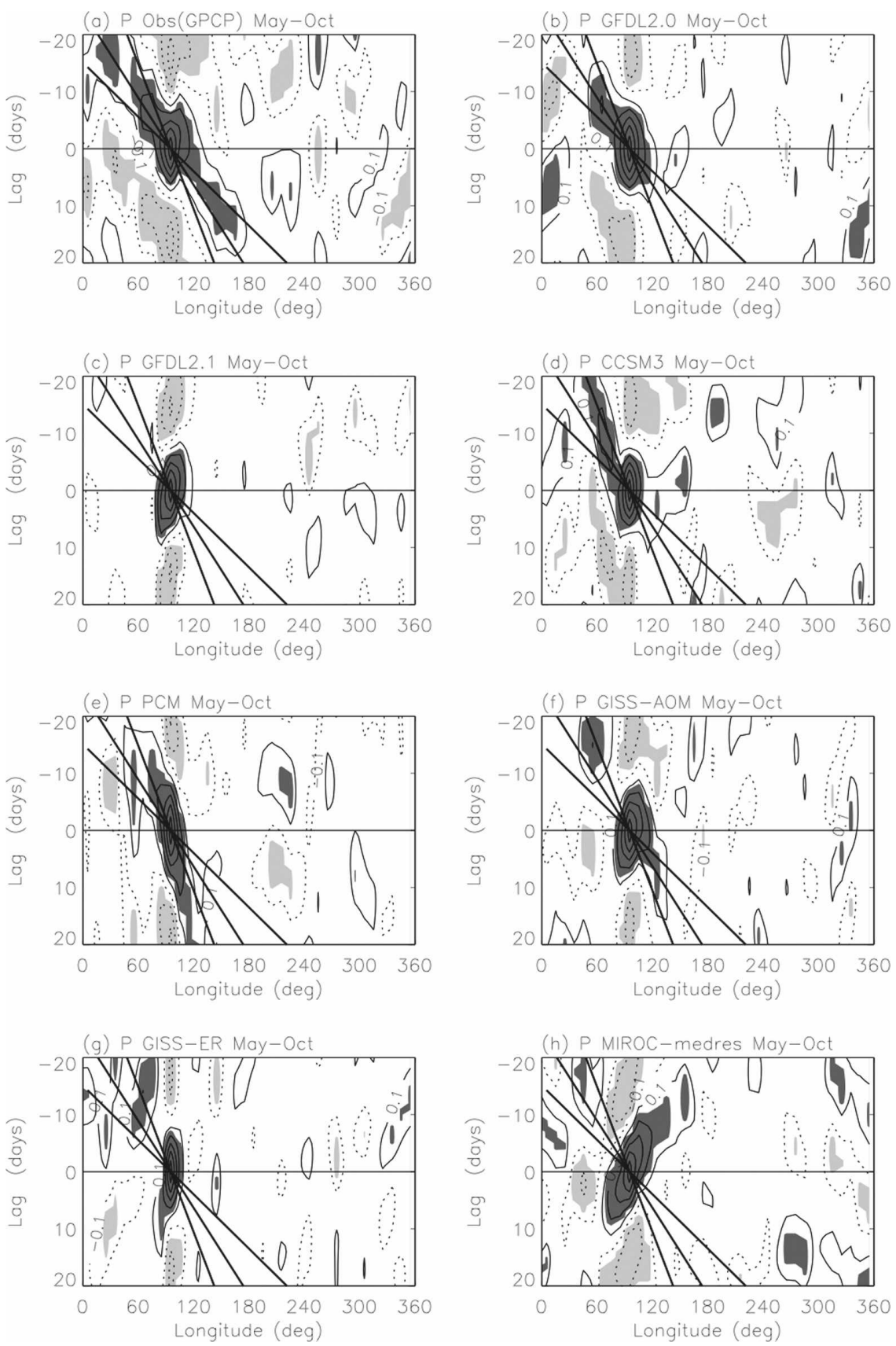

FIG. 11. Lag correlation of the 24-70-day precipitation anomaly averaged between $5^{\circ}$ and $25^{\circ} \mathrm{N}$ with respect to itself at $15^{\circ} \mathrm{N}, 95^{\circ} \mathrm{E}$ : (a), (i) observations and (b)-(h), (j)-(p) 14 IPCC AR4 models. Shading denotes the regions where lag correlation is above the $95 \%$ confidence level. The three thick lines correspond to phase speeds of 3,5 , and $8 \mathrm{~m} \mathrm{~s}^{-1}$, respectively.

\section{d. The northward component of BSIO}

Next we look at the variance of the northward component of BSIO (hereafter BSIO-N), that is, the daily variance of the northward 24-70-day mode. Figures $14 \mathrm{a}, \mathrm{b}$ show the variance of the BSIO-N anomaly averaged between $70^{\circ}$ and $100^{\circ} \mathrm{E}$ (the ISM region), and between $120^{\circ}$ and $160^{\circ} \mathrm{E}$ (the WNPSM-EASM region) For both regions, the BSIO-N variance is less than half of the observed value in nine models. There is no oneto-one correspondence between the models with large BSIO-N variance (more than half the observed) and those with large BSIO-E variance (Fig. 9). Two models do simulate large variance for both BSIO-E and 

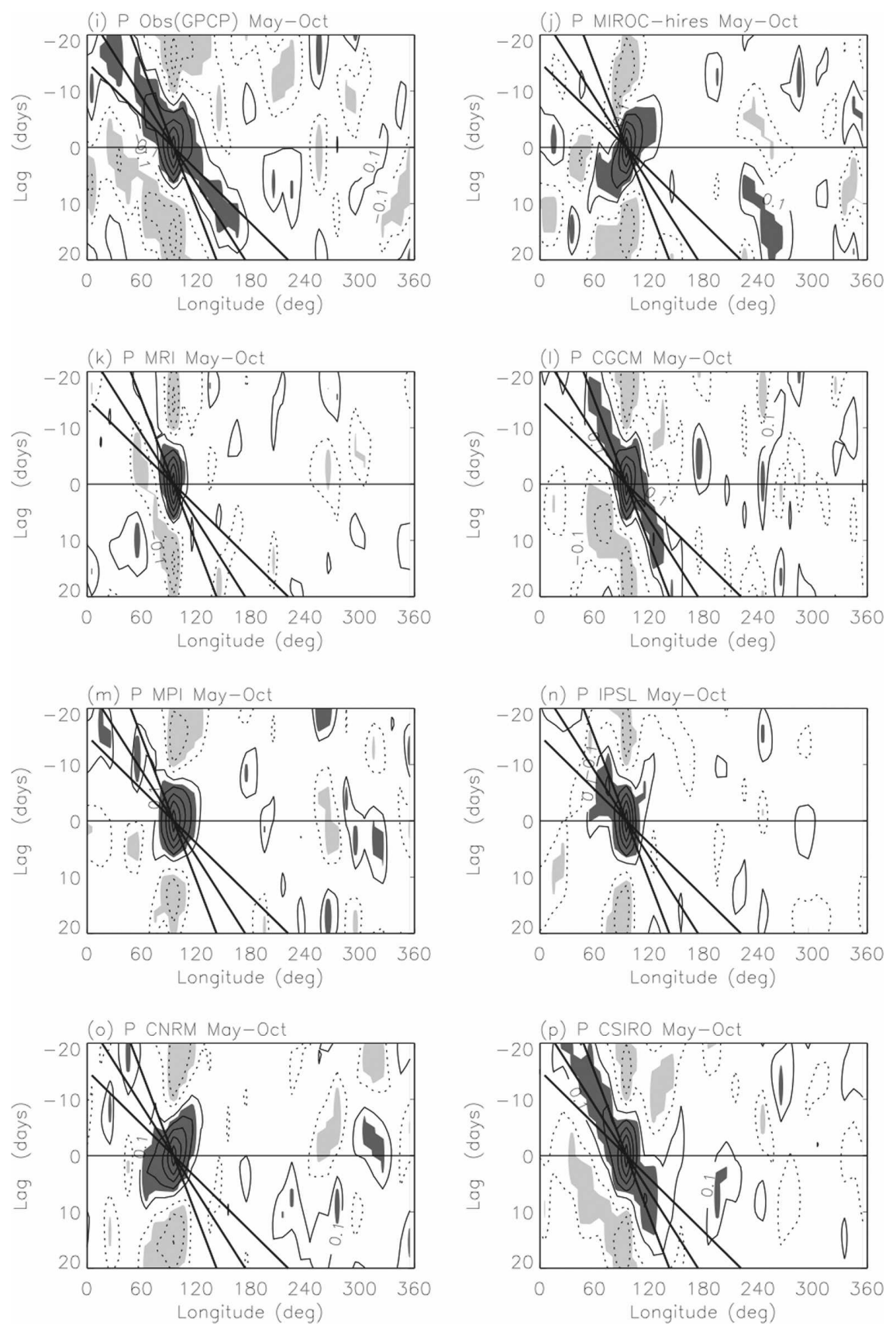

FIG. 11. (Continued)

BSIO-N (MPI and CNRM), but some only simulate large BSIO-N variance (GFDL2.0, GFDL2.1, and MIROC-medres), and one model only simulates large BSIO-E variance (CGCM). When the northward BSIO-N variance is larger than its southward counterpart, the tropical intraseasonal oscillation events tend to have more northward events than southward events, as is the case in observations.

Figures $15 \mathrm{a}, \mathrm{b}$ show the ratio between the northward
BSIO-N variance and the variance of its southward counterpart averaged over an ISM box between $5^{\circ}-$ $20^{\circ} \mathrm{N}$ and $70^{\circ}-100^{\circ} \mathrm{E}$, and a WNPSM box between $5^{\circ}-$ $20^{\circ} \mathrm{N}$ and $120^{\circ}-160^{\circ}$ E. Over the ISM region (Fig. 15a), the northward BSIO-N variance roughly quadruples the southward variance in observation. Most of the models simulate a large ratio that is larger than two, although only one model (CNRM) produces a ratio that is larger than the observed value. This is in sharp 

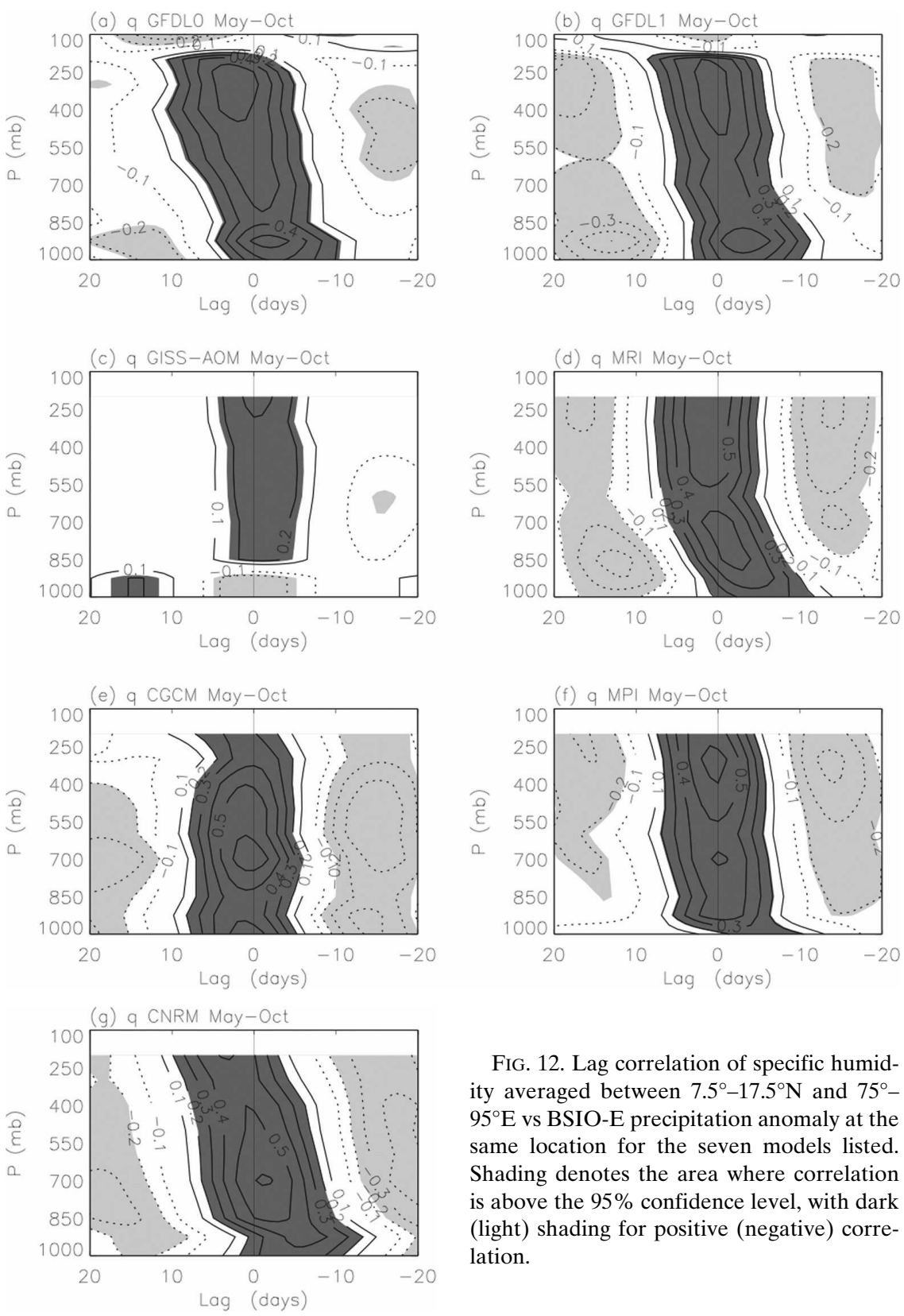

FIG. 12. Lag correlation of specific humidity averaged between $7.5^{\circ}-17.5^{\circ} \mathrm{N}$ and $75^{\circ}-$ $95^{\circ} \mathrm{E}$ vs BSIO-E precipitation anomaly at the same location for the seven models listed. Shading denotes the area where correlation is above the $95 \%$ confidence level, with dark (light) shading for positive (negative) correlation.

contrast with the models' inability to simulate a large eastward/westward ratio for BSIO-E. Over the WNPSM region (Fig. 15b), again, the northward BSIO-N variance nearly triples its southward counterpart in observation, and most of the models do produce a large ratio that is larger than 1.5.

Again, following the analysis used for E-W propagation, the competition between the northward BSIO-N variance and its southward counterpart largely determines the meridional propagation characteristics of intraseasonal precipitation anomalies. Figure 16 shows the lag correlation of 24-70-day precipitation anomaly

averaged between $70^{\circ}$ and $100^{\circ} \mathrm{E}$ with respect to itself at $12.5^{\circ} \mathrm{N}, 85^{\circ} \mathrm{E}$. The observational data show prominent northward propagating signals of the BSIO-N, with a phase speed of about $1.8 \mathrm{~m} \mathrm{~s}^{-1}$. Most of the models display a highly coherent northwardpropagating signal that is consistent with the large ratio between the northward BSIO-N variance and its southward counterpart shown in Fig. 15a. The only model with the ratio being nearly equal to one (GISS-AOM) shows a standing oscillation. The results are similar for the WNPSM region (not shown).

To summarize, the BSIO-N variance is too small in 

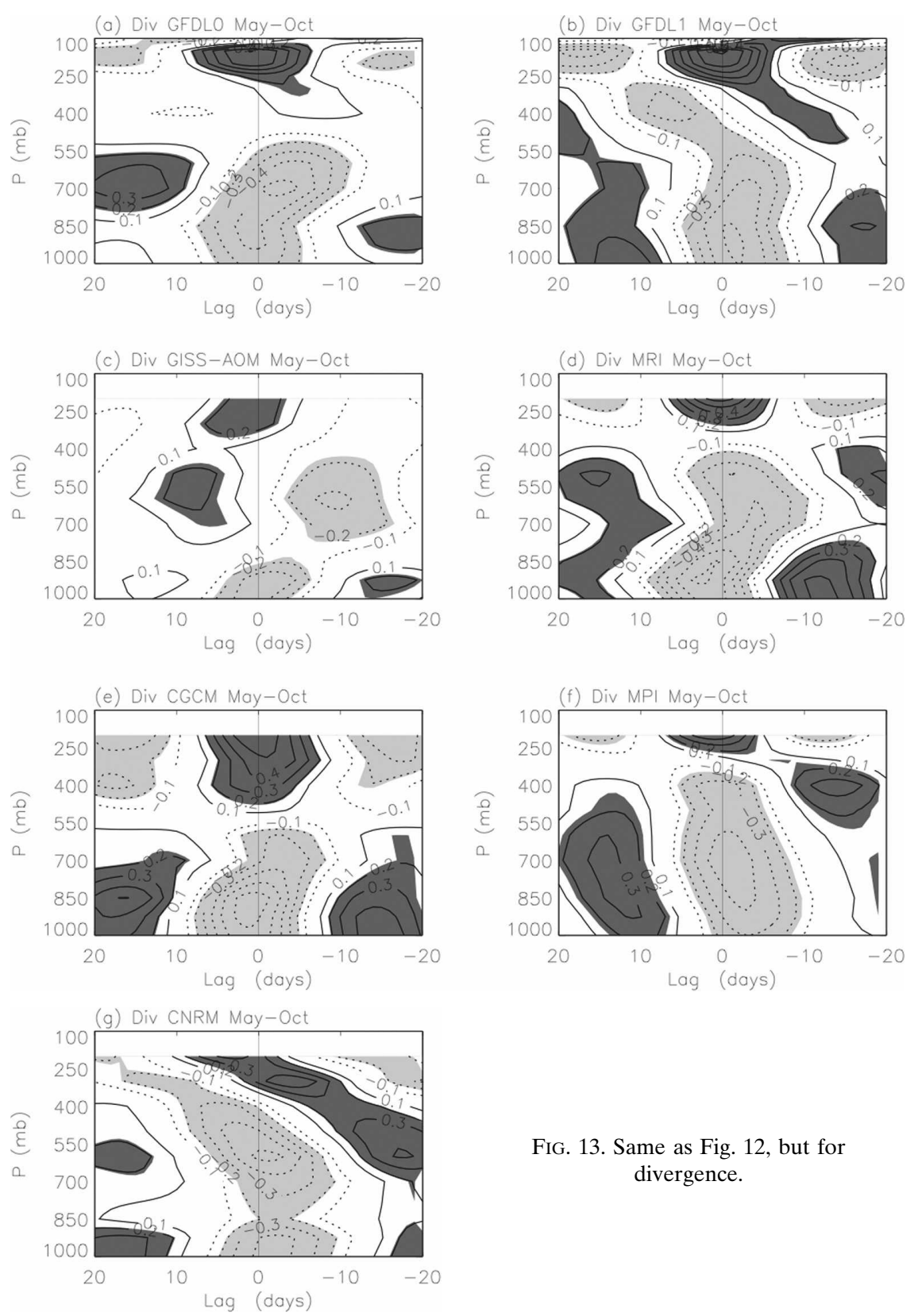

FIG. 13. Same as Fig. 12, but for divergence.

all models, and less than half of the observed value in the nine models. There is no one-to-one correspondence between the models with large BSIO-N variance and those with large BSIO-E variance, although two models (MPI and CNRM) do simulate large variance for both BSIO-E and BSIO-N. The ratio between the northward BSIO-N variance and the variance of its southward counterpart is too small but still at least half of the observed value in most of the models, consistent with the highly coherent northward propagation of the BSIO-N in many models.

\section{e. The 12-24-day mode}

Figure 17 shows the variance of the westward 12-24day mode averaged between $10^{\circ}$ and $20^{\circ} \mathrm{N}$. Two of the 14 models (MPI and MRI) simulate overly large variance of the 12-24-day mode, and 5 other models (CNRM, CSIRO, GFDL2.1, MIROC-medres, and MIROC-hires) produce variance that is more than half of the observed value. However, the observed variance has its maximum over western Pacific but in some of the models the maximum is over the Indian Ocean (e.g., 

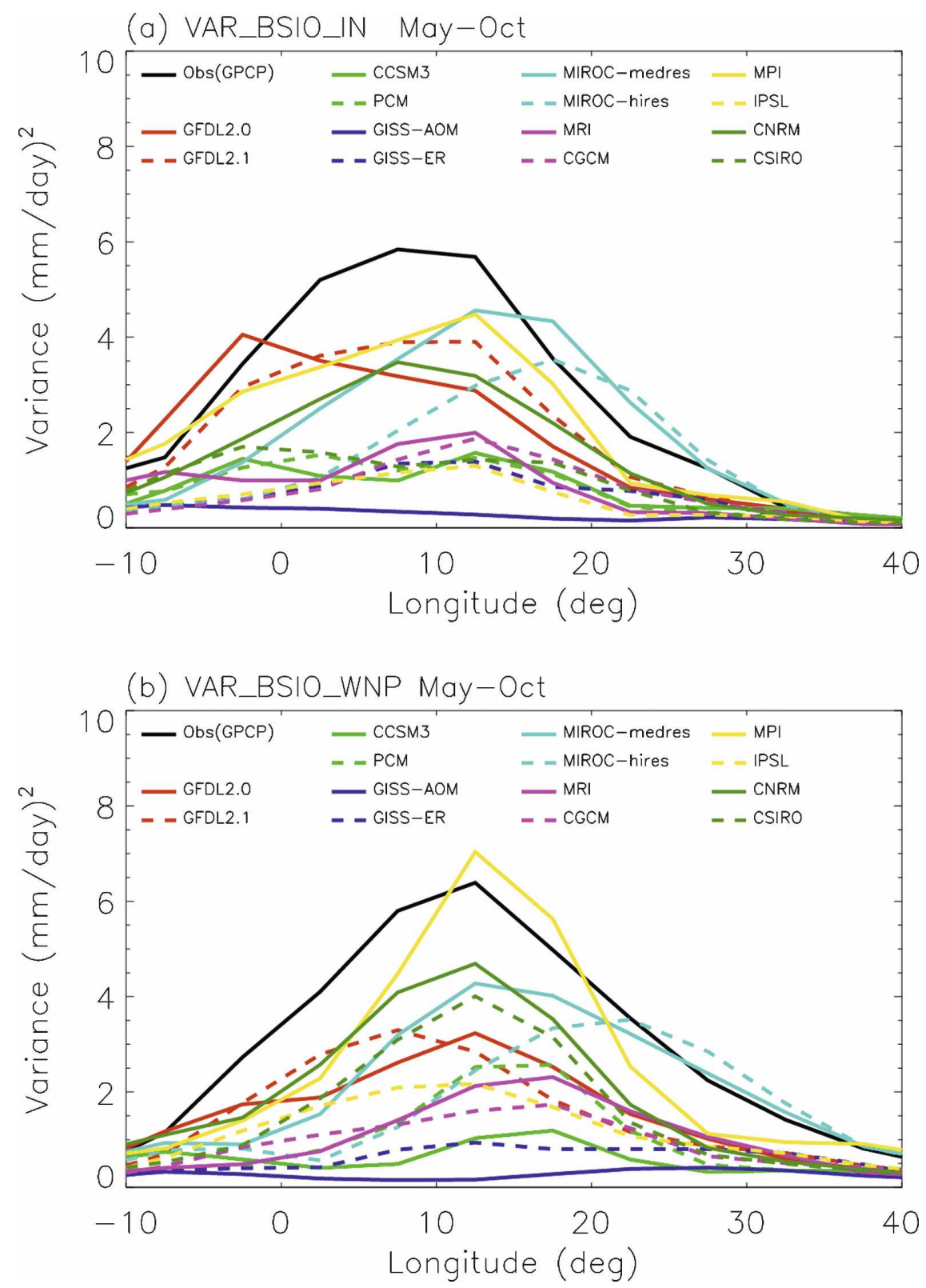

FIG. 14. Variance of the northward component of BSIO averaged (a) between $70^{\circ}$ and $100^{\circ} \mathrm{E}$, and (b) between $120^{\circ}$ and $160^{\circ} \mathrm{E}$ for observations and 14 models.

MIROC-medres and MIROC-hires), which may be connected with their excessive seasonal-mean precipitation (Fig. 4a) and total subseasonal variance (Fig. 7a) in that region.

Figure 18 shows the ratio between the variance of the westward 12-24-day mode and that of its eastward counterpart averaged over a western Pacific box between $10^{\circ}-20^{\circ} \mathrm{N}$ and $120^{\circ}-170^{\circ} \mathrm{E}$. In observation, the westward variance is roughly double the eastward variance. All models simulate a ratio larger than one (i.e., westward variance dominates over eastward variance), and more than half of the models simulate an overly large ratio. As a result, most of the models display a highly coherent westward propagation of the 12-24-day mode (not shown).

In summary, the variance of the 12-24-day mode is typically too small, but rises to at least half of the observed value in half of the 14 models, and is even overly large in two models. Highly coherent westward propagation of the 12-24-day mode is seen in most of the models. 

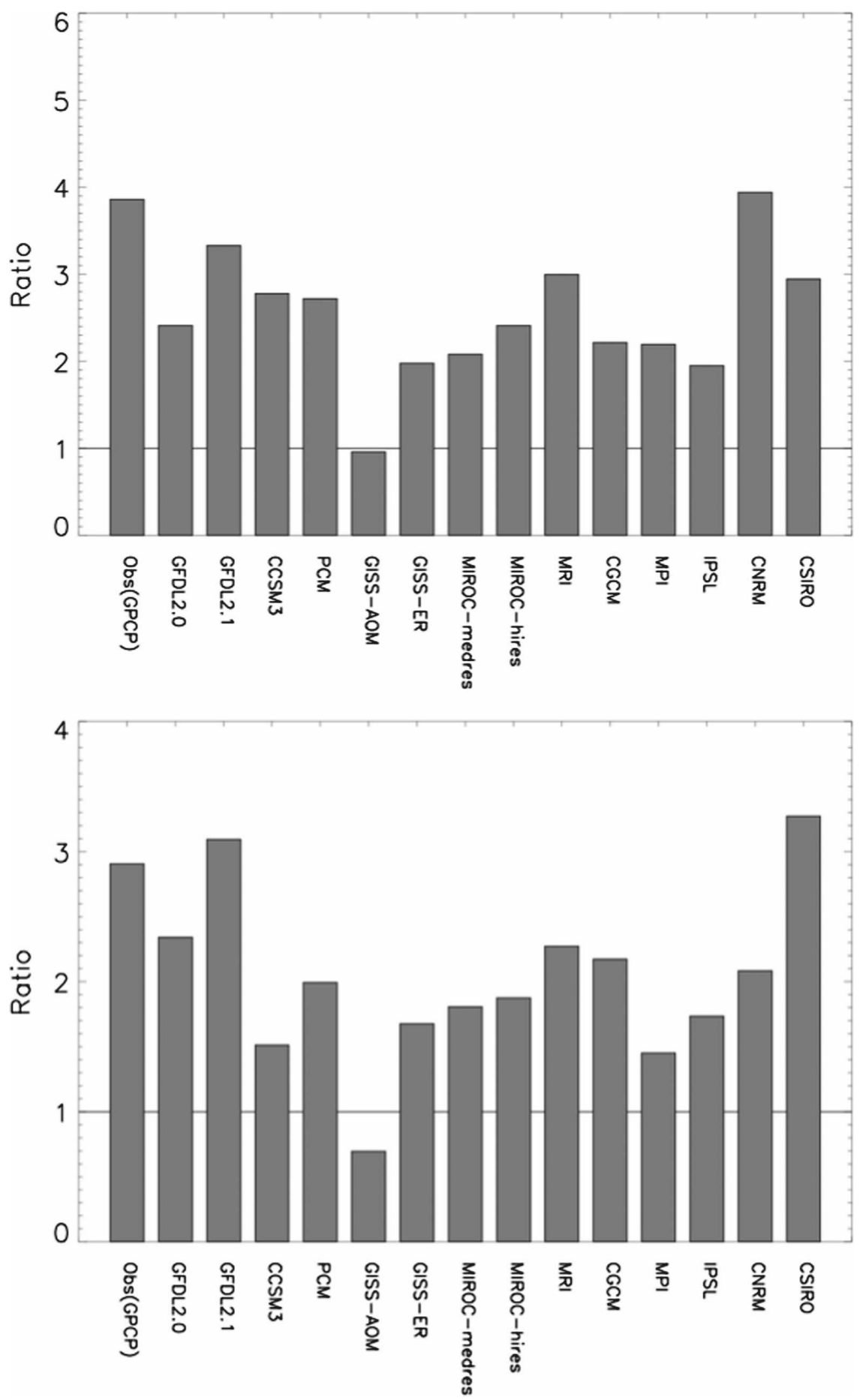

FIG. 15. Ratio between the variance of the northward component of BSIO and the variance of its southward counterpart (southward 24-70-day mode) for observations and 14 models. The variances are averaged over (a) an Indian summer monsoon box between $5^{\circ}-20^{\circ} \mathrm{N}$ and $70^{\circ}-100^{\circ} \mathrm{E}$, and (b) a western North Pacific summer monsoon box between $5^{\circ}-20^{\circ} \mathrm{N}$ and $120^{\circ}-160^{\circ} \mathrm{E}$. 

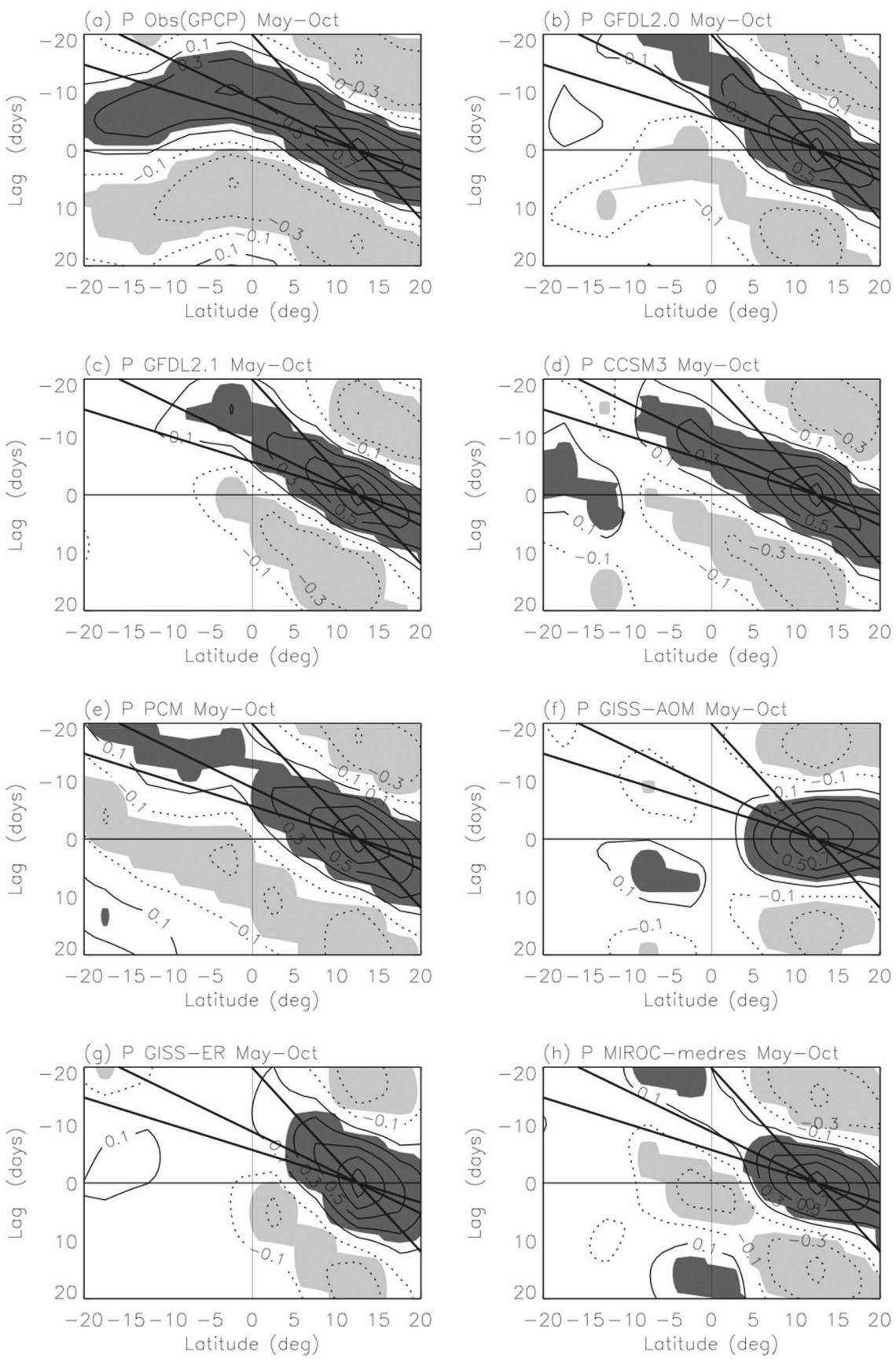

FIG. 16. Lag correlation of the 24-70-day precipitation anomaly averaged between $70^{\circ}$ and $100^{\circ} \mathrm{E}$ with respect to itself at $12.5^{\circ} \mathrm{N}, 85^{\circ} \mathrm{E}$ : (a), (i) observations and (b)-(h), (j)-(p) 14 IPCC AR4 models. Shading denotes the regions where lag correlation is above the $95 \%$ confidence level. The three thick lines correspond to phase speeds of $0.8,1.8$, and $2.8 \mathrm{~m} \mathrm{~s}^{-1}$, respectively.

\section{Summary and discussion}

The results above show that current state-of-the-art GCMs display a wide range of skill in simulating the subseasonal variability associated with Asian summer monsoon. During boreal summer (May-October), most of the models produce reasonable seasonal-mean precipitation over the ISM region, but excessive precipitation over the WNPSM region and insufficient precipitation over the EASM region. In other words, models concentrate their rain too close to the equator in the western Pacific. Most of the models simulate overly 

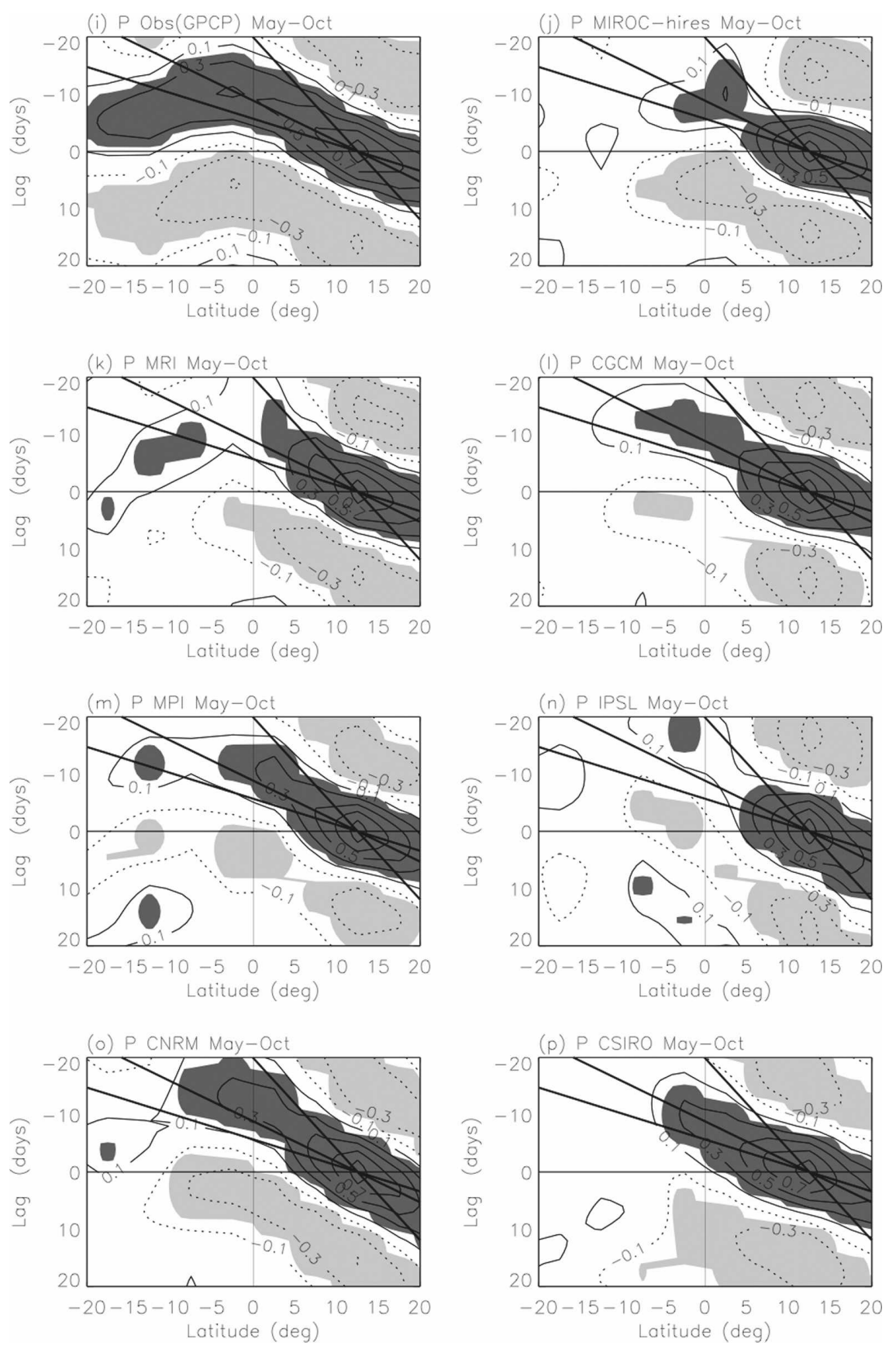

FIG. 16. (Continued)

weak total subseasonal (2-128 day) variance, as well as too little variance for BSIO and the 12-24-day mode. Only 4-5 models produce spectral peaks in the BSIO and 12-24-day frequency bands; instead, most of the models display too red a spectrum, that is, an overly strong persistence of precipitation. For the seven models with three-dimensional data available, five reproduce the preconditioning of moisture in BSIO but often with a too-late starting time, and only three simulate the phase lead of low-level convergence. Interestingly, although models often have difficulty in simulating the eastward propagation of BSIO, they tend to simulate well the northward propagation of BSIO, together with the westward propagation of the 12-24-day mode.

As discussed in the introduction, factors hypothesized to be important for simulating boreal summer intraseasonal variability include air-sea coupling, model resolution, and model physics. Regarding air-sea 


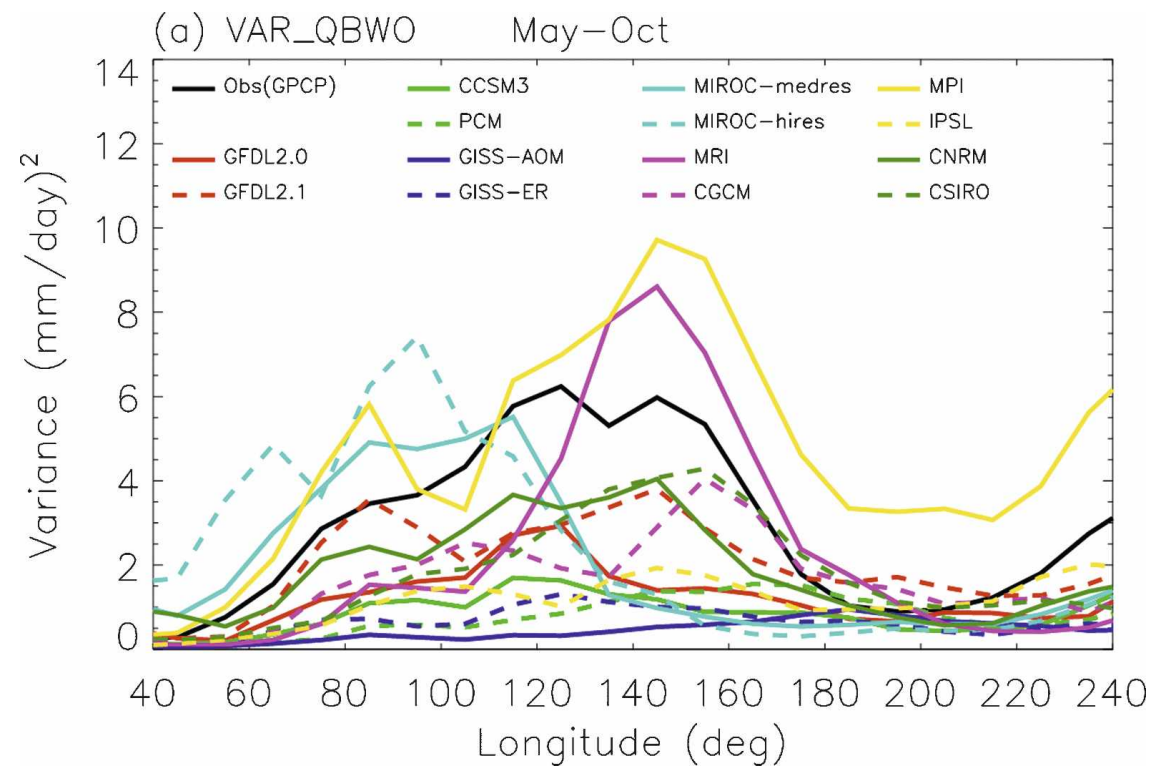

FIG. 17. Variance of the 12-24-day mode averaged between $10^{\circ}$ and $20^{\circ} \mathrm{N}$ for observations and 14 models.

coupling, all models analyzed in this study are coupled GCMs, but they still have significant difficulties in simulating the subseasonal variability. However, previous studies have shown that the effects of coupling de- pend strongly on the background state for both the MJO simulation (e.g., Inness et al. 2003) and the simulation of the Asian summer monsoon (Turner et al. 2005). Without detailed experimentation using coupled

(a) VAR_W/VAR_E 10N2ON May-Oct

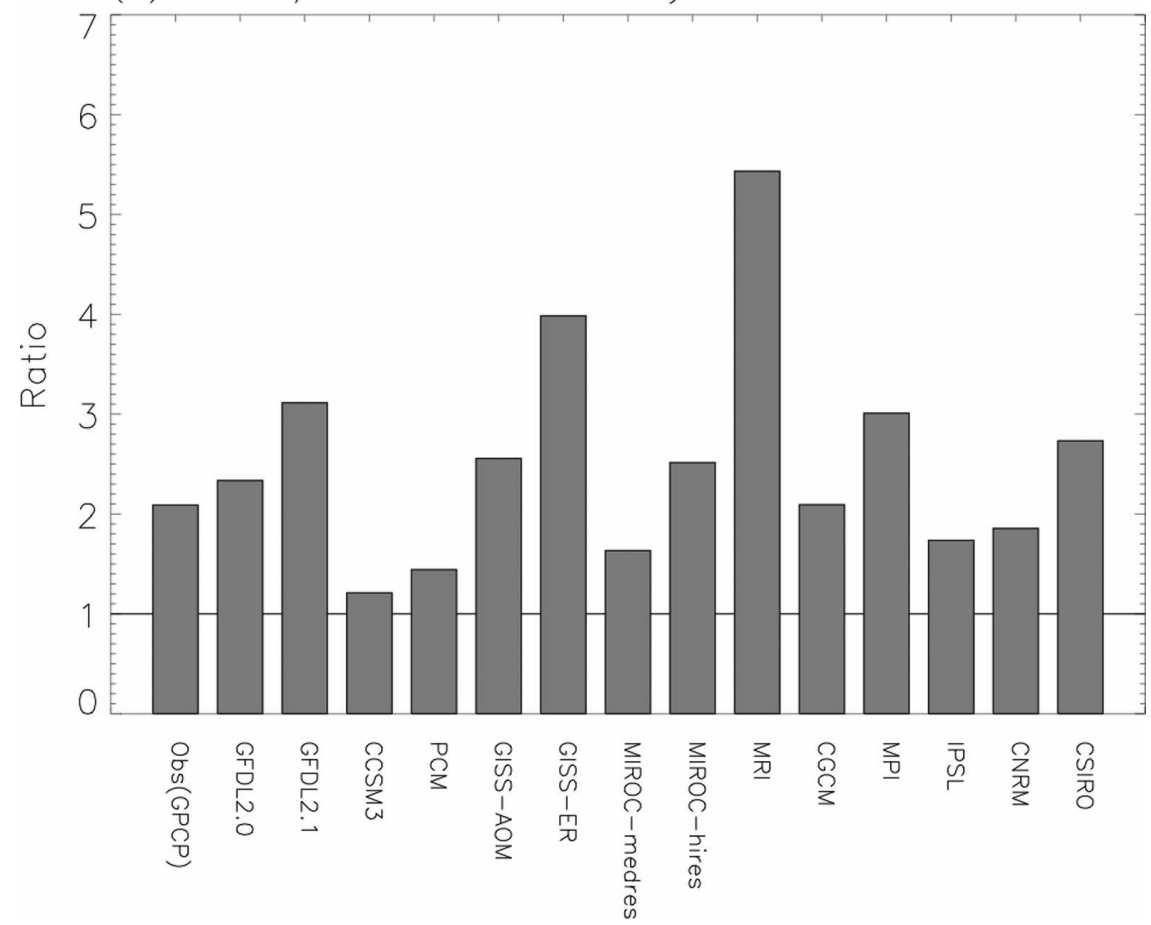

FIG. 18. Ratio between the variance of the westward 12-24-day mode and the variance of its eastward counterpart (eastward 12-24-day mode) for observations and 14 models. The variances are averaged over $10^{\circ}-20^{\circ} \mathrm{N}$ and $120^{\circ}-170^{\circ} \mathrm{E}$. 
and uncoupled versions of the same model with similar mean states, few firm conclusions can be drawn. Moreover, since most coupled models are only exchanging air-sea or air-land fluxes once every $24 \mathrm{~h}$, more frequent coupling may be necessary.

Regarding model resolution, we have only one pair of similar atmospheric models but with different resolution: MIROC-hires (T106) versus MIROC-medres (T42). Higher model resolution does not increase the variances of either BSIO (Fig. 9) or 12-24-day mode (Fig. 17), although it slightly improves the westward propagation of the 12-24-day mode (Fig. 18).

Regarding model physics, our results may suggest a few speculations. First, although there is no one-to-one correspondence between the models with large BSIO-E variance (Fig. 9) and those with large BSIO-N variance (Fig. 14), two models do simulate large variance for both BSIO-E and BSIO-N (MPI and CNRM), and they are the only models with convective closure/trigger linked to moisture convergence. As shown by Lin et al. (2006), these two models also do the best in simulating the boreal winter MJO. In contrast, in a set of 1990s era AMIP models, Slingo et al. (1996) found that deep convection schemes with convective available potential energy (CAPE)-type closure tend to produce more realistic MJO signals than schemes with moistureconvergence-type closures. This peculiar reversal may just be a coincidence among a sample of just a handful of models, although perhaps we can at least conclude that convective closures-triggers may be a key aspect of model physics, in determining how convection feeds back on large-scale transient circulations like the MJO and BSIO.

Second, an overly red spectrum of precipitation is seen in many models (overly strong persistence of equatorial precipitation). As discussed in Lin et al. (2006), the persistence of equatorial precipitation may be amenable to improvement via changes in moist physics, for example, by including self-suppression processes in tropical deep convection such as moisture triggers (i.e., dryness cutoffs), and the effects of convective and mesoscale downdrafts. Recently, Lin et al. (2008) found that adding moisture convective trigger to the convection schemes of an AGCM significantly improves the model-simulated convectively coupled equatorial waves. More works are needed on the impacts on Asian summer monsoon and associated subseasonal variability, and on the effects of convective and mesoscale downdrafts.

An interesting result of this study is that many models simulate well the northward propagation of BSIO in spite of their difficulties in simulating the eastward propagation of BSIO. This may be because the east- ward propagation and northward propagation are caused by different mechanisms. For the eastward propagation, the mechanisms suggested by theoretical studies include the frictional wave-CISK (e.g., Wang and Rui 1990; Salby et al. 1994; Moskowitz and Bretherton 2000), charge-discharge (e.g., Blade and Hartmann 1993; Hayashi and Golder 1997; Raymond 2001; Khouider and Majda 2006), and air-sea coupling (e.g., Flatau et al. 1997; Wang and Xie 1998; Waliser et al. 1999) theories. We have evaluated the corresponding features of the first two mechanisms in Fig. 12 and Fig. 13, respectively. For the northward propagation, theoretical and observational studies have suggested several different mechanisms, including land surface heat flux (Webster 1983; Srinivasan et al. 1993), Rossby wave emanation (Wang and Xie 1996), vertical-shearinduced boundary layer moisture convergence (Jiang et al. 2004), moisture advection (Jiang et al. 2004), and ocean surface sensible heat flux (Hsu et al. 2004). Since in both observation and many IPCC AR4 models the strongest northward-propagating signals appear over the northern Indian Ocean or western Pacific Ocean (Fig. 14), the land surface heat flux may not play a significant role. Since many models producing good northward-propagating signals fail to produce eastward-propagating signals, the northward propagation is thus evidently not simply a NW-SE-tilted tail protruding off of an eastward-moving deep-tropical intraseasonal oscillation, at least in these models. In future studies, analyses of heat, moisture, and vorticity budgets are needed to examine if other mechanisms mentioned above contribute to the northward signals in the models.

Acknowledgments. Gary Russell kindly provided detailed description of the GISS-AOM model. We acknowledge the international modeling groups for providing their data for analysis, the Program for Climate Model Diagnosis and Intercomparison (PCMDI) for collecting and archiving the model data, the JSC/ CLIVAR Working Group on Coupled Modeling (WGCM) and their Coupled Model Intercomparison Project (CMIP) and Climate Simulation Panel for organizing the model data analysis activity, and the IPCC WG1 TSU for technical support. The IPCC Data Archive at Lawrence Livermore National Laboratory is supported by the Office of Science, U.S. Department of Energy. J. L. Lin was supported by the U.S. CLIVAR CMEP Project, NOAA CPO/CVP Program, and NASA MAP Program. G. N. Kiladis was supported by NOAA CPO under Grant GC05-156. B. E. Mapes was supported by the NOAA CPO/CVP program and by CPO/CPPA Grant GC05-039. 


\section{REFERENCES}

Blade, I., and D. L. Hartmann, 1993: Tropical intraseasonal oscillations in a simple nonlinear model. J. Atmos. Sci., 50, 2922 2939.

Bougeault, P., 1985: A simple parameterization of the large-scale effects of cumulus convection. Mon. Wea. Rev., 113, 21082121.

Chen, T.-C., and J.-M. Chen, 1993: The 10-20-day mode of the 1979 Indian Monsoon: Its relation with the time variation of monsoon rainfall. Mon. Wea. Rev., 121, 2465-2482.

$\longrightarrow$, and - 1995: An observational study of the South China Sea Monsoon during the 1979 summer: Onset and life cycle. Mon. Wea. Rev., 123, 2295-2318.

— M.-C. Yen, and S.-P. Weng, 2000: Interaction between the summer monsoons in East Asia and the South China Sea: Intraseasonal monsoon modes. J. Atmos. Sci., 57, 1373-1392.

Del Genio, A. D., and M.-S. Yao, 1993: Efficient cumulus parameterization for long-term climate studies: The GISS scheme. The Representation of Cumulus Convection in Numerical Models, Meteor. Monogr., No. 46, Amer. Meteor. Soc., 181184.

Duchan, C. E., 1979: Lanczos filtering in one and two dimensions. J. Appl. Meteor., 18, 1016-1022.

Emanuel, K. A., 1987: An air-sea interaction model of intraseasonal oscillations in the Tropics. J. Atmos. Sci., 44, 2324-2340.

_ 1991: A scheme for representing cumulus convection in large-scale models. J. Atmos. Sci., 48, 2313-2329.

Emori, S., T. Nozawa, A. Numaguti, and I. Uno, 2001: Importance of cumulus parameterization for precipitation simulation over East Asia in June. J. Meteor. Soc. Japan, 79, 939-947.

Flatau, M., P. J. Flatau, P. Phoebus, and P. P. Niiler, 1997: The feedback between equatorial convection and local radiative and evaporative processes: The implications for intraseasonal oscillations. J. Atmos. Sci., 54, 2373-2386.

Fu, X., and B. Wang, 2004a: Differences of boreal summer intraseasonal oscillations simulated in an atmosphere-ocean coupled model and an atmosphere-only model. J. Climate, 17, $1263-1271$.

_, and _ 2004b: The boreal-summer intraseasonal oscillations simulated in a hybrid coupled atmosphere-ocean model. Mon. Wea. Rev., 132, 2628-2649.

$\longrightarrow,-$, T. Li, and J. P. McCreary, 2003: Coupling between northward-propagating, intraseasonal oscillation and sea surface temperature in the Indian Ocean. J. Atmos. Sci., 60, 1733-1753.

Fukutomi, Y., and T. Yasunari, 1999: 10-25 day intraseasonal variation of convection and circulation over East Asia and western North Pacific during early summer. J. Meteor. Soc. Japan, 77, 753-769.

— and - 2002: Tropical-extratropical interaction associated with the 10-25 day oscillation over the western Pacific during the northern summer. J. Meteor. Soc. Japan, 80, 311-331.

Gregory, D., and P. R. Rowntree, 1990: A mass flux convection scheme with representation of cloud ensemble characteristics and stability-dependent closure. Mon. Wea. Rev., 118, 1483-1506.

Hartmann, D. L., M. L. Michelsen, and S. A. Klein, 1992: Seasonal variations of tropical intraseasonal oscillations: A 20-25 day oscillation in the western Pacific. J. Atmos. Sci., 49, 1277 1289.

Hayashi, Y., and D. G. Golder, 1997: United mechanisms for the generation of low- and high-frequency tropical waves. Part I:
Control experiments with moist convective adjustment. $J$. Atmos. Sci., 54, 1262-1276.

Hsu, H.-H., and C.-H. Weng, 2001: Northwestward propagation of the intraseasonal oscillation in the western North Pacific during the boreal summer: Structure and mechanism. J. Climate, 14, 3834-3850.

- - , and C.-H. Wu, 2004: Contrasting characteristics between the northward and eastward propagation of the intraseasonal oscillation during the boreal summer. J. Climate, 17, 727-743.

Huffman, G. J., R. F. Adler, M. M. Morrissey, S. Curtis, R. Joyce, B. McGavock, and J. Susskind, 2001: Global precipitation at one-degree daily resolution from multisatellite observations. J. Hydrometeor., 2, 36-50.

Inness, P., and J. Slingo, 2003: Simulation of the Madden-Julian oscillation in a coupled general circulation model. Part I: Comparison with observations and an atmosphere-only GCM. J. Climate, 16, 345-364.

- - — E. Guilyardi, and J. Cole, 2003: Simulation of the Madden-Julian oscillation in a coupled general circulation model. Part II: The role of the basic state. J. Climate, 16, 365-382.

Jiang, X., T. Li, and B. Wang, 2004: Structures and mechanisms of the northward propagating boreal summer intraseasonal oscillation. J. Climate, 17, 1022-1039.

Kemball-Cook, S., and B. Wang, 2001: Equatorial waves and airsea interaction in the boreal summer intraseasonal oscillation. J. Climate, 14, 2923-2942.

- — , and X. Fu, 2002: Simulation of the intraseasonal oscillation in the ECHAM-4 model: The impact of coupling with an ocean model. J. Atmos. Sci., 59, 1433-1453.

Khouider, B., and A. J. Majda, 2006: A simple multicloud parameterization for convectively coupled tropical waves. Part I: Linear analysis. J. Atmos. Sci., 63, 1308-1323.

Kiladis, G. N., and K. M. Weickmann, 1997: Horizontal structure and seasonality of large-scale circulations associated with submonthly tropical convection. Mon. Wea. Rev., 125, 19972013.

$\longrightarrow$, K. H. Straub, and P. T. Haertel, 2005: Zonal and vertical structure of the Madden-Julian oscillation. J. Atmos. Sci., 62, 2790-2809.

Knutson, T. R., K. M. Weickmann, and J. E. Kutzbach, 1986: Global-scale intraseasonal oscillations of outgoing longwave radiation and $250 \mathrm{mb}$ zonal wind during Northern Hemisphere summer. Mon. Wea. Rev., 114, 605-623.

Krishnamurti, T. N., and P. Ardanuy, 1980: The 10- to 20-day westward propagating mode and "breaks in the monsoon." Tellus, 32, 15-26.

Lau, K.-H., and N.-C. Lau, 1990: Observed structure and propagation characteristics of tropical summertime synoptic scale disturbances. Mon. Wea. Rev., 118, 1888-1913.

Lau, K. M., and P. H. Chan, 1986: Aspects of the 40-50 day oscillation during the northern summer as inferred from outgoing longwave radiation. Mon. Wea. Rev., 114, 1354-1367.

, G. J. Yang, and S. H. Shen, 1988: Seasonal and intraseasonal climatology of summer monsoon rainfall over East Asia. Mon. Wea. Rev., 116, 18-37.

Lawrence, D. M., and P. J. Webster, 2002: The boreal summer intraseasonal oscillation: Relationship between northward and eastward movement of convection. J. Atmos. Sci., 59, 1593-1606.

Liebmann, B., H. H. Hendon, and J. D. Glick, 1994: The relationship between tropical cyclones of the western Pacific and 
Indian Oceans and the Madden-Julian oscillation. J. Meteor. Soc. Japan, 72, 401-412.

Lin, J. L., 2007: The double-ITCZ problem in IPCC AR4 coupled GCMs: Ocean-atmosphere feedback analysis. J. Climate, 20, 4497-4525.

— B. B. Mapes, M. H. Zhang, and M. Newman, 2004: Stratiform precipitation, vertical heating profiles, and the Madden-Julian oscillation. J. Atmos. Sci., 61, 296-309.

_- M. H. Zhang, and B. E. Mapes, 2005: Zonal momentum budget of the Madden-Julian oscillation: The sources and strength of equivalent linear damping. J. Atmos. Sci., 62, 2172-2188.

— , and Coauthors, 2006: Tropical intraseasonal variability in 14 IPCC AR4 climate models. Part I: Convective signals. J. Climate, 19, 2665-2690.

—, M.-I. Lee, D. Kim, I.-S. Kang, and D. Frierson, 2008: Impacts of convective parameterization and moisture triggering on AGCM-simulated convectively coupled equatorial waves. J. Climate, 21, 883-909.

Moorthi, S., and M. J. Suarez, 1992: Relaxed Arakawa-Schubert: A parameterization of moist convection for general circulation models. Mon. Wea. Rev., 120, 978-1002.

Moskowitz, B. M., and C. S. Bretherton, 2000: An analysis of frictional feedback on a moist equatorial Kelvin mode. J. Atmos. Sci., 57, 2188-2206.

Murakami, T., 1980: Empirical orthogonal function analysis of satellite-observed outgoing longwave radiation during summer. Mon. Wea. Rev., 108, 205-222.

—_, and T. Nakazawa, 1985: Tropical 45 day oscillation during the 1979 Northern Hemisphere summer. J. Atmos. Sci., 42, 1107-1122.

Neelin, J. D., I. M. Held, and K. H. Cook, 1987: Evaporation-wind feedback and low-frequency variability in the tropical atmosphere. J. Atmos. Sci., 44, 2341-2348.

Nordeng, T. E., 1994: Extended versions of the convective parameterization scheme at ECMWF and their impact on the mean and transient activity of the model in the tropics. Tech. Memo. 206, European Centre for Medium-Range Weather Forecasts, Reading, United Kingdom, 41 pp.

Pan, D.-M., and D. A. Randall, 1998: A cumulus parameterization with a prognostic closure. Quart. J. Roy. Meteor. Soc., 124, 949-981.

Raymond, D. J., 2001: A new model of the Madden-Julian oscillation. J. Atmos. Sci., 58, 2807-2819.

Rui, H., and B. Wang, 1990: Development characteristics and dynamic structure of tropical intraseasonal convection anomalies. J. Atmos. Sci., 47, 357-379.

Russell, G. L., J. R. Miller, and D. Rind, 1995: A coupled atmosphere-ocean model for transient climate change studies. Atmos.-Ocean, 33, 683-730.

Salby, M. L., R. B. Garcia, and H. H. Hendon, 1994: Planetaryscale circulations in the presence of climatological and waveinduced heating. J. Atmos. Sci., 51, 2344-2367.

Slingo, J. M., and Coauthors, 1996: Intraseasonal oscillations in 15 atmospheric general circulation models: Results from an AMIP diagnostic subproject. Climate Dyn., 12, 325-357.

Sperber, K. R., J. M. Slingo, and H. Annamalai, 2000: Predictability and the relationship between subseasonal and interannual variability during the Asian summer monsoon. Quart. J. Roy. Meteor. Soc., 126, 2545-2574.

- , and Coauthors, 2001: Dynamical seasonal predictability of the Asian summer monsoon. Mon. Wea. Rev., 129, 22262248 .
Srinivasan, J., S. Gadgil, and P. J. Webster, 1993: Meridional propagation of large-scale monsoon convective zones. $\mathrm{Me}$ teor. Atmos. Phys., 52, 15-35.

Straub, K. H., and G. N. Kiladis, 2003: Interactions between the boreal summer intraseasonal oscillation and higher-frequency tropical wave activity. Mon. Wea. Rev., 131, 945-960.

Tiedtke, M., 1989: A comprehensive mass flux scheme for cumulus parameterization in large-scale models. Mon. Wea. Rev., 117, 1779-1800.

Tokioka, T., K. Yamazaki, A. Kitoh, and T. Ose, 1988: The equatorial 30-60-day oscillation and the Arakawa-Schubert penetrative cumulus parameterization. J. Meteor. Soc. Japan, 66, 883-901.

Turner, A. G., P. M. Inness, and J. M. Slingo, 2005: The role of the basic state in the ENSO-monsoon relationship and implications for predictability. Quart. J. Roy. Meteor. Soc., 131, 781804.

Vincent, D. G., A. Fink, J. M. Schrage, and P. Speth, 1998: Highand low-frequency intraseasonal variance of OLR on annual and ENSO time scales. J. Climate, 11, 968-986.

Waliser, D. E., K.-M. Lau, and J.-H. Kim, 1999: The influence of coupled sea surface temperatures on the Madden-Julian oscillation: A model perturbation experiment. J. Atmos. Sci., 56, 333-358.

— S. Schubert, A. Kumar, K. Weickmann, and R. Dole, 2003a: Proceedings from a workshop on "Modeling, Simulation and Forecasting of Subseasonal Variability." NASA/CP 2003104606, Vol. 25, 62 pp.

— W. Stern, S. Schubert, and K. M. Lau, 2003b: Dynamic predictability of intraseasonal variability associated with the Asian Summer Monsoon. Quart. J. Roy. Meteor. Soc., 129, 2897-2925.

— variability associated with the Asian Summer Monsoon. Climate Dyn., 21, 423-446.

Wang, B., and H. L. Rui, 1990: Synoptic climatology of transient tropical intraseasonal convective anomalies: 1975-1985. Meteor. Atmos. Phys., 44, 43-61.

- , and X. Xie, 1996: Low-frequency equatorial waves in vertically sheared zonal flow. Part I: Stable waves. J. Atmos. Sci., 53, 449-467.

— , and -1998 : Coupled modes of the warm pool climate system. Part I: The role of air-sea interaction in maintaining Madden-Julian oscillations. J. Climate, 8, 2116-2135.

_ , and LinHo, 2002: Rainy season of the Asian-Pacific summer monsoon. J. Climate, 15, 386-398.

Webster, P. J., 1983: Mechanisms of monsoon low-frequency variability: Surface hydrological effects. J. Atmos. Sci., 40, 2110 2124.

Wheeler, M., and G. N. Kiladis, 1999: Convectively coupled equatorial waves: Analysis of clouds and temperature in the wavenumber-frequency domain. J. Atmos. Sci., 56, 374-399.

$\mathrm{Wu}$, M. L. C., S. Schubert, I.-S. Kang, and D. Waliser, 2002: Forced and free intraseasonal variability over the south asian monsoon region simulated by 10 AGCMs. J. Climate, 15, 2862-2880.

Yasunari, T., 1979: Cloudiness fluctuations associated with the northern hemisphere summer monsoon. J. Meteor. Soc. Japan, 57, 227-242.

Zhang, G. J., and N. A. McFarlane, 1995: Sensitivity of climate simulations to the parameterization of cumulus convection in the CCC-GCM. Atmos.-Ocean, 3, 407-446. 